NCBI Bookshelf. A service of the National Library of Medicine, National Institutes of Health.

Reinisch J. The Perils of Peace: The Public Health Crisis in Occupied Germany. Oxford (UK): OUP Oxford; 2013 Jun 6.

\title{
Chapter 2 A Hard Peace? Allied Preparations for the Occupation of Germany, 1943-1945
}

I have said, and say again, that the German nation needs the most drastic cure in history, and that, if it is not applied, the world will die of the German disease ... [W] e are not concerned with all old, unhappy, far-off things but with what Germany has done to her neighbours in our century, and how and why. 1

The problem of what was to be done with Germany after its defeat had been under consideration since at least December 1941 and the Japanese attack on Pearl Harbor. In the course of the next three years, the British, American, and Soviet leaders - not yet joined by the French — debated in a series of conferences and summits the principles that were to guide their post-war treatment of, and conduct in, the defeated country. These deliberations shaped the course of the post-war era: Germany would be occupied, stripped of its military and industrial capabilities, and cleansed of Nazi influences. It would be asked to pay compensation to those countries who had suffered. Most importantly, it would be prevented from threatening peace and stability again.

After spring 1943, when the 'unconditional surrender' formula was agreed, plans focused primarily on the organization of military governments and the appointment of leading officers and their staffs. Planners also began to draft arrangements for problems such as the handling of prisoners of war, civil internees, and displaced persons; the control of German agriculture, industries, and mines; and the coordination of military government departments with German local and regional governments. In addition, some gave first thought to the denazification of German authorities, while others drafted plans for the operation of basic public health services on German soil. These plans posited that public health work, both in the short and long term, was to be conducted by existing German authorities (therefore only indirectly a concern of the occupiers), but they noted that some military government-directed epidemic work would have to proceed at the early stages and was a crucial element of the occupation.

For much of the war the only significant preparations for occupation took place in Washington and London: both governments had staffs familiar with the administration of overseas colonies and territories, both were able to devote manpower and resources to the problem of Germany and were willing to collaborate with each other. The Soviet government, by contrast, concentrated on the war effort itself and was distrustful of Anglo-American motivations and agendas. The French government-in-exile not only did not feature as an occupying power until later, but had few resources to contribute to these efforts. Only later did the Soviet and French authorities rush to catch up, often by copying and adapting British and American plans and policies.

This chapter analyses the Allied plans for the post-war occupation of Germany. It shows that decisions and agreements reached in Washington and London fundamentally shaped the entire occupation framework until the creation of the two German Republics in 1949, and beyond - a fact about which the Soviet and French leaders later frequently complained. Recurring themes on 'the German problem', particularly the belief in a dominant and totalitarian national German character, influenced these preparations and conditioned the early stages of the occupation. Public health officers faced a number of dilemmas: their efforts to prevent the spread of infectious diseases had to proceed in a country under strict military control; Germany had to restrict its industrial capacities and pay compensation to its victims, but without damaging the health of its population. These problems were exacerbated by the fact that public health work among the German population initially ranked far below more pressing military and political priorities.

\section{American and British plans for the Occupation of Germany}

\section{(i) Starting premises}

General guidelines for the political treatment of Germany crystallized in the course of the wartime meetings and conferences of the Big Three. Within these parameters planning staffs in London and Washington worked out detailed directives for specific issues. From the start there were tensions between the United States, Britain, and the Soviet Union, but some basic purposes and assumptions bound them together: they agreed that, in the interest of world security, Nazism had to be defeated and Germany's war potential had to be destroyed. The principle of an 'unconditional surrender', announced at Churchill and Roosevelt's meeting in Casablanca in January 1943, signalled that the Allies would fight until they had achieved Germany's total defeat; no successors to the National Socialist 
government would be able to negotiate the terms of peace. Fears that this formula would prolong the war notwithstanding, Roosevelt and Churchill insisted that the mistakes of the First World War were not to be repeated, that the German population would be dealt with firmly. ${ }^{2}$ But, apart from these general premises, the conferences of Casablanca, Moscow, and Teheran left open many questions of future Allied policy in Germany. Even the work of the inter-Allied European Advisory Commission (EAC), a body set up to coordinate future occupation policy, suffered from a general lack of certainty as to what should happen. $\frac{3}{-}$

Separate British and American bodies, such as the British Foreign Office and its Research Department (FORD) and the US War Department's Civil Affairs Division, conducted research on Germany's existing governmental structures and drafted plans for future administration. These plans were integrated and coordinated in Anglo-American organizations such as the offices of the Chief of Staff to the Supreme Allied Commander (COSSAC), later turned into the G5 Division of the Anglo-American joint command Supreme Headquarters Allied Epeditionary Force (SHAEF). Public health came under the aegis of 'civil affairs'. Some of these preparations began immediately after the outbreak of war, but the early work concentrated almost exclusively on war strategy. From the end of 1941, much of the planning work was overseen by the newly created Combined Chiefs of Staff Committee. This body, responsible to the British prime minister and the American president, produced plans for an invasion of the European continent and the shape of military governments.

Some of this work concerned itself with the training of future military government officers. Barely half a year after the United States had entered the war, the first School of Military Government opened its doors on the campus of the University of Virginia in Charlottesville to train officers for work in civil affairs headquarters. Here, the "stress was on military government problems and their solution in terms applicable to a large variety of local situations, but under conditions basically like those in Burma and Bulgaria in that they involved an occupying army and an indigenous enemy — or allied — population'. Foreign language instruction was not part of this training, and the 'foreign area study' was 'sketchy and only suggestive of many possible situations in different parts of the world'. ${ }^{4}$ By June 1943, less generic training commenced in (eventually) ten Civil Affairs Training Schools, known as CATS, all based at universities who appointed a civilian director. Courses were taught by specialists in fields such as local government, farming, industry, commerce, public welfare, public safety, and public health. Courses for work in Europe lasted between eight and twelve weeks, and up to six months for the Japanese programme. The director of the Central European area programme of the CATS at Stanford, John Brown Mason, explained that 'attention was paid to the kind of knowledge and local points of view that would help the civil affairs officer to understand the people with whom he must deal and to meet effectively the problems which he was likely to encounter. These needs called for special attention to the study of national psychology, political customs and philosophies, religious convictions and outlooks, inherited attitudes, pattern of thought (or nonthought) acquired under the monopolistic propaganda of Nazism, recent history, and so forth.' However, even here, Mason argued, not enough consideration was given to the particularities of individual countries. More seriously, Mason argued in 1950 that the differences between military government in enemy and Allied countries were 'not sufficiently appreciated during training', and '[w] hile the occupation of Allied countries would be necessary, it would also be temporary and of a basically different character [from that in enemy countries]' Here, 'problems would be quite different from those encountered in enemy states, they called for other attitudes and methods.,$\stackrel{5}{-}$

After relatively slow beginnings, planning for the occupation and training of military government officers accelerated rapidly in the aftermath of the Casablanca conference of January 1943, which confirmed that Germany's borders would be changed as conquered territories would be returned, that dismemberment or some kind of division into zones was likely, and that the Allies would occupy the country for a significant but unspecified period of time. The Casablanca meeting also made clear that occupation forces would have to supervise basic administrative functions until a central German government could be reinstalled.

After Casablanca, preparations concentrated on the division of responsibilities within the military government machinery. Initially, it was to be based on the organization of the British and American armies, and then to be turned into a Control Commission, mirroring the organization of German local government. The term 'military government' originally referred to the sum of all occupation troops in Germany, but was increasingly used to describe occupation officers in the different zones. ${ }^{6}$ These bodies quickly produced a deluge of acronyms: the British contingent was the Control Commission for Germany (British Element), or CCG(BE); the American the United States Group Control Council, USGCC, later turned into the Office of Military Government, United States, known as OMGUS. The Soviet operation was to be the Sovietskaya Voyennaya Administracia v Germanii, SVAG, or Soviet Military Administration in Germany, SMAG. When at the last minute the French were added, they administered their zone through the 
Commandement en Chef Français en Allemagne, the CCFA, and the Gouvernement Militaire de la Zone Française d'Occupation, referred to as GMZFO.

The commanders-in-chief from each of the occupying powers-Dwight Eisenhower, Bernard Montgomery, and Georgy Zhukov (eventually joined by Pierre Koenig) — were to form the highest authority in each zone. They were to decide Germany-wide questions within the Allied Control Council (ACC). The ACC's directorates and the departments of the occupation authorities in each zone were to mirror the relevant German authorities, to which they would leave the execution of policy. German ministries were to be seized on surrender and continued under Allied control. The administration of civil affairs (which included public health) was to be part of the many responsibilities of the Internal Affairs and Communications Division.

As plans for these structures emerged during the second half of 1943 and 1944, planning staffs also began to compile manuals and handbooks to familiarize officers with German history, major German institutions, and Allied policy. Most were not overtly political, but they frequently incorporated popular and academic analyses of the German problem, such as the identification of Prussia as the source of fascism and authoritarianism, the existence of a pervasive militarist tradition, and the psychological nature of Nazism, analogous to the mental state of schizophrenia (of which the carrier was often unaware). A guide on 'The Mentality of the Germany Officer', for example, set out to 'trace the development of [the German's] curious mentality through earlier years'. It discussed issues such as the influence of German traditions on military officers, German attitudes to the Versailles treaty, German officers' obsession with 'honour', and how to manage German soldiers after defeat. It concluded that while Allied troops had to prepare themselves for dealing with the Germans' 'ferocious fanaticism' and 'contempt of moral restraint', their assignment was assisted by the likelihood of 'fierce factional splits among them', which, 'combined with the fact that the Germans as liars are clumsy and transparent (far inferior to the Latins)', would make their work easier. ${ }^{7}$

A paper entitled 'The German Character' explained to Allied troops some of the attributes of the German psyche, such as 'an abnormal respect for authority', 'an inferiority complex due in part to Germany's late start as a nation, a guilt complex resulting from misdeeds, and at the same time an awareness of great gifts and talents'. The 'average German', this paper stated, had a tendency towards 'fanatical extremist tendencies' and an 'unswaying loyalty' to leaders, which meant defeat was likely to lead to reactions such as 'hysteria, running amok, killings and destruction of others or self'. In what was later to become an important theme in the selection and appointment of Germans to administrative jobs, the paper insisted that the population could not be 'divided into two classes, good and bad Germans'. Rather, there were 'good and bad elements in the German character, the latter of which generally predominate'. The paper also warned that Allied officers should not be deceived by Germans' attempts to befriend occupation officers, as they would try to divide the occupation powers. ${ }^{8}$ The paper also included a list of 'Some Do's and Don't's', spelling out how Allied officers were to conduct themselves (see Fig. 2.1).

In addition to these manuals, planning staffs compiled a series of handbooks and technical guides. ${ }^{9}$ The German refugee Francis Carsten was one of a group of native German speakers recruited by the British Political Warfare Executive to assist in their preparation. He was told, he remembered later, that '[ $t]$ hey didn't want to be caught unprepared as in the case of the First World War'. Carsten was involved in the preparation of the Basic German Handbook, which, he remembered, 'contained factual information on Germany-National Socialist Germany as well as pre-Nazi Germany — on administration, legal system, educational system, Nazi political organisations' background, et cetera'. Carsten and his colleagues were briefed not 'to give any political advice, being enemy aliens. This was left to the Foreign Office and the Ministry of Economic Warfare.' Instead, he and his fellow refugees 'were only to provide factual information on what was the state of affairs in Germany and what was the situation a British officer coming into a German town would find there as regard to local government or local education or public utilities or whatever'. The handbooks, Carsten remembered, were widely distributed and very popular, since 'the large majority of these British officers who went into Germany had no knowledge of German and so this was all they could rely on when they went in'. 10

In the last year of the war, instructions and guidelines were displayed most prominently in the SHAEF Handbook for Military Government. Drafts from April and June 1944 attempted to lay out concisely the methods by which military government officers were to administer and supervise German affairs. ${ }^{11}$ Officers would have to ensure that the German governmental machinery ran efficiently, and this would best be achieved if the centralized German administrative system was retained. It was likely that the Allies would have to subsidize German economic development for some time, and that a range of commodities and relief supplies would have to be imported. ${ }^{12}$ Although these drafts acknowledged that food would be scarce all over Europe, they nonetheless set the target for German rations at 2,000 
calories per person per day, i.e. at the same level set for the populations of the non-Axis liberated countries. An August 1944 draft of another handbook, the Manual for Administration and Local Government in Germany, made similar recommendations: it stated that because the war damage in Germany was likely to be extensive, it was in the interests of Allied officers to focus on resolving housing and economic problems. ${ }^{13}$ A number of scholars' recommendations strengthened this conclusion. The Harvard sociologist Talcott Parsons, for example, argued in 1944 that lasting 'institutional change' demanded 'a policy of fostering a highly productive, full-employment, expanding economy for Germany. The inherent tendencies of the modern, industrial economy are such that if this is achieved its influence on institutional change will be automatically in the right direction. 14

However, a number of factors complicated and slowed the preparation of concrete plans. Germany's future was just one of many Allied preoccupations. Numerous strategic decisions had to be made regarding campaigns and operations in North Africa, France, Italy, Poland, and the Soviet Union, and arrangements for the redeployment of troops to the Pacific. Britain was heavily dependent on American credits and would have to urgently rebuild its export trade. The future of Germany was vital, certainly, but as Michael Balfour, a member of the British Element of the Control Commission in Berlin, remarked: 'Giving the German question the importance due to it was easily confused with favouring the cruel enemy at the expense of the unfortunate victim. 15

The coordination of the different Allied governments' diverging interests was at times difficult, but internal divisions were also significant. The Roosevelt administration was divided by a long-running struggle between the Department of State and the War Department, which centred largely on the role of the armed forces in occupation and military government. The War Department argued that 'the demands of military necessity and unity of command' precluded civilian responsibilities, and that it was impossible for civilian agencies to operate independently until military operations had been completed. ${ }^{16}$ To counter that, ideological objections about the wisdom of giving political power to soldiers were voiced repeatedly, but by November 1943 Roosevelt eventually directed the War Department to take charge of planning, because it was 'quite apparent that if prompt results are to be obtained the Army will have to assume the initial burden'. ${ }^{17}$ While it had not been proven that civilians would not perform occupation duties better than soldiers, the argument that they could not perform them at all during a world war and its aftermath was powerful and influential. $\frac{18}{}$

The American debates over occupation responsibilities were mirrored, to a lesser degree, by differences between the British government's War Office and Foreign Office. Responsibility for the administration of Germany was tossed back and forth between them because of changing ideas on the nature of military occupation. Until March 1944, the occupation was to be supervised by the War Office; then a revision handed responsibility to the Foreign Office, until in June 1945 the War Office took over again. In October 1945 a special agency, the Control Office for Germany and Austria (COGA) was set up to coordinate the two. However, military government officers continued to report directly to the Foreign Office, bypassing the War Office and particularly COGA, which was dissolved soon after its establishment. ${ }^{19}$ However, British officials, just like their American colleagues, ultimately came to the conclusion that civilian responsibility for the administration of an occupied country was, for the near future at least, not viable. ${ }^{20}$

As a result of these divisions, both governments were constrained by the prevailing uncertainties and displayed great unwillingness to commit to any specific directions too early. Both Roosevelt and Churchill delayed firm decisions. In October 1944, Roosevelt told his Secretary of State, Cordell Hull, that it was 'all very well for us to make all kinds of preparations for the treatment of Germany, but there are some matters in regard to such treatment that lead me to believe that speed on these matters is not an essential at the present moment ... I dislike making detailed plans for a country which we do not yet occupy.' 21 Churchill voiced similar reservations. As late as February 1945, he argued that it was 'much too soon for us to decide these enormous questions ... I shall myself prefer to concentrate upon the practical issues which will occupy the next two or three years, rather than argue about the long-term relationship of Germany to Europe ... There is ... wisdom in reserving one's decision as long as possible and until all the facts and forces that will be potent at the moment are revealed. ${ }^{22}$ 'Practical issues' such as war strategy and specific operations in France and Germany were prioritized, and preparations for the future of a defeated Germany were marked by a lack of direction and an unwillingness to commit. ${ }^{23}$

\section{(ii) The Morgenthau Plan}

Up to this point, preparations were conducted by two well-oiled bureaucratic machines, while the political leaderships were distracted by more urgent problems and unwilling to commit to any specific proposals. In both Washington and London, civil servants drew upon a familiar set of procedures while preparing for the German occupation: they trained 
staff, conducted research into likely scenarios, compiled handbooks. The result was a set of preparations similar in tone and substance to plans produced for other countries, with little strategic thought about what the Allies wanted to achieve in Germany.

It was in this context that in August 1944 the Morgenthau Plan entered the planning arena, when Henry Morgenthau, secretary of the US Treasury, prepared a comprehensive scheme on the political and economic treatment of Germany after surrender. ${ }^{24} \mathrm{He}$ criticized what he perceived to be a widespread emphasis in American circles on German 'reconstruction'. Such tendencies, he maintained, could be identified in the official memoranda. The SHAEF Handbook seemed to convey the impression that a transformation of Germany could be achieved by forbidding National Socialism and improving living conditions. If these directives were to guide American conduct, Morgenthau argued, any change of German society was going to be superficial and temporary. Germany's participation in a third world war could not be prevented by the kind of controls that had been imposed after 1918. Experience had shown that factories converted to peacetime production could always be converted back; that the destruction of industries only had a temporary effect; and that banning Nazism would only drive it underground. Allied military governments would not be able to supervise Germany for ever. ${ }^{25}$ Policy in Germany would have to be fundamentally different from operations in countries liberated from Nazi control.

The key to the German problem, according to Morgenthau, lay in economics. Germany would only become peaceful if it was transformed into an agrarian society, if its industrial base was stripped away, and if the industries vital to military strength were dismantled and transported to other nations as a form of restitution. A military occupation would have to prevent their re-establishment, and would have to continue for at least twenty years. During this time Germany should receive no economic aid. In fact, the Allies should not 'assume responsibility for such economic problems as price controls, rationing, housing, or transportation, or take any measure designed to maintain or strengthen the German economy, except those which are essential to military operations' ${ }^{26}$ Conditions should not be allowed to be better than those prevailing in Germany's poor and war-ridden neighbours.

The fate of the Morgenthau Plan is well known. Roosevelt initially supported it, but the Foreign Office, the State Department, and a series of economic advisers objected to at least some of its proposals. Reparations would have to be extracted in a more viable way, they argued, or else Germany would become a heavy burden on Allied governments and taxpayers. Although the plan was never fully or even partially implemented, a number of (primarily German) historians have ascribed to it great influence. ${ }^{27}$

It did have a number of consequences. Most importantly, the debates it triggered signalled to planners that the occupation of Germany was different from other Allied projects. Some of the plan's premises and specific clauses were taken up in later policy. The notion of a 'Carthaginian peace' (similar in spirit to the settlement imposed by the Romans on Carthage), gave some shape to the vague formula of 'unconditional surrender'. Specifically, German living conditions (and features such as the health service) were now treated as part and extension of the German state's war machine, to be dealt with accordingly. This proved to be of fundamental importance for the planning of public health operations. In the absence of other clear directions, the plan signified a move towards a 'hard peace'. Aspirations of toughness predominated thereafter, and handbooks and outline plans were rewritten to conform to these new standards. Planning staff's wariness of going beyond the political premises of a 'hard peace' resulted in a lack of policy in many areas, which was preferable to the accusation of having exceeded 'the bounds of strict military necessity'. ${ }^{28}$

From September 1944, preparations were different in tone. They emphasized the differences between liberated countries and Germany, and declared that the standard of living could not be allowed to be higher in Germany than elsewhere. In that month, after the third and fourth drafts of the SHAEF Handbook were withdrawn as 'too soft', the Combined Chiefs of Staff ordered that all existing work on Germany was to be supplemented by three principles. First, no steps towards the economic rehabilitation of Germany were to be undertaken; the responsibility for maintaining existing conditions lay exclusively with German authorities. Second, no relief supplies were to be imported or distributed beyond the minimum necessary to prevent disease and disorder, and only insofar as these might hamper military operations. This was particularly crucial to the planning of health work. Third, all Nazis and Nazi sympathizers were to be punished systematically and all Nazi organizations were to be dissolved. ${ }^{29}$ Subsequent editions of the Handbook incorporated these principles. As a result, the later drafts of the public health section of the Handbook focused on the pervasiveness of Nazi ideology in the health service, rather than, as before, the achievements and successes of German public health and social medicine before $1933 .{ }^{30}$

At the same time, General Eisenhower, supreme commander of the Allied Forces in Europe, instructed his forces in September 1944 in just these terms about the conduct of the occupying forces in Germany. ${ }^{31}$ A few months later, a 
December 1944 directive on the 'procedures to be employed in the military government of occupied Germany' spelled out the new guiding principles. The 'essence' of Allied policy was that 'no effort will be made to rehabilitate or succor the German people. Rather, sole aim of the Military Government is to further military objectives.' It went on:

All planning, direction and instruction by US elements concerning military governments should be guided by this policy which reflects firm US views as known in this Headquarters. Principal points to be emphasized are the following:

a. Germany will not be 'liberated', but occupied as a defeated nation.

b. The German people will be made to realize that all necessary steps will be taken to prevent any further attempt by them to conquer the world.

c. No steps will be taken looking toward the economic rehabilitation of Germany nor designed to maintain or strengthen the German economy except those needed to prevent epidemics or serious diseases and serious civil disorder which would endanger the forces and to prevent the dissipation or sabotage of German equipment required for Allies countries. 32

This focus was vital, the directive stated, because '[r]eports from the field indicate that the Military Government Detachments and G5 staffs of subordinate formations are inclined to try to do too much to relieve the problems of the German people. There seems to be a disposition to approach the administration of Germany with the idea that it is our job to make Germany a "happy land" again. It is essential that all Military Government personnel be disabused of this concept.' Finally, it added, the 'position of this Headquarters is equally firm with regard to fraternisation'.33

The Morgenthau Plan also left traces in the major planning directive which guided the American occupation until 1947, the document known as JCS 1067. ${ }^{34}$ This directive underwent numerous draft editions, reflecting the process of working out a compromise between the various views within the US government. Its final version (the eighth) was issued to Eisenhower on 14 May 1945. It contained measures on the reorganization of industry and administrative structures, but overall emphasis was placed on the prohibition of attempts to facilitate or aid German recovery. Although a major purpose of occupation was to bring democracy to Germany, the country was to be treated as a 'defeated enemy'. 'It should be brought home to the Germans', it stated, 'that Germany's ruthless warfare and the fanatical Nazi resistance have destroyed the German economy and made chaos and suffering inevitable and that the Germans cannot escape responsibility for what they have brought upon themselves. 35

The directive instructed Eisenhower that Germany 'will not be occupied for the purpose of liberation but as a defeated enemy nation. Your aim is not oppression but to occupy Germany for the purpose of realizing certain important Allied objectives. In the conduct of your occupation and administration you should be just, but firm and aloof. You will strongly discourage fraternization with the German officials and population. ${ }^{36}$ Finally, it emphasized that responsibility for all matters of German survival, welfare, and government would have to be shouldered by German officials. Assistance from the occupation forces in the provision of food and relief goods was limited to the minimum necessary 'to prevent disease and unrest'. There were clear implications for public health work: health operations had to be oriented towards military necessity, and the burden of work had to be carried by German authorities. 'You will estimate the requirements of supplies necessary to prevent starvation or widespread disease or such civil unrest as would endanger the occupying forces,' JCS 1067 instructed Eisenhower, and

[s]uch estimates will be based upon a program whereby the Germans are made responsible for providing for themselves, out of their own work and resources. You will take all practicable economic and police measures to assure that German resources are fully utilized and consumption held to the minimum in order that imports may be strictly limited and that surpluses may be made available for the occupying forces and displaced persons and United Nations prisoners of war, and for reparation. You will take no action that would tend to support basic living standards in Germany on a higher level than that existing in any one of the neighboring United Nations. ${ }^{37}$

\section{Plans for Public Health}

\section{(i) Public health as 'civil affairs'}


Preparations for public health work in the countries liberated or occupied by the Allied armies came under the aegis of 'civil affairs', which, apart from public health, included issues such as the distribution of relief supplies, the liaison with local religious representatives, the care of displaced persons, the establishment of basic civil administrations, and the restoration of police and justice systems. Civil affairs ranked relatively low down in the hierarchy of military plans, suffering not only from the vague and shifting political objectives that affected all planning, but also from the fact that priority was given to combat operations. In his official history of the British civil affairs teams, F. S. V. Donnison observed that civil affairs staffs were often seen as an obstacle to military success. Even though their concerns were going to be essential for the period after defeat, it was 'sometimes hard for a commander to see Civil Affairs officers in this light. At a time when he is bending all energy and resources to the overcoming of his enemy, Civil Affairs staffs can easily appear as impediments rather than aids to his operations. ... [T] hey frequently are demanding "lift" for relief supplies, protesting against requisitioning (or looting), standing up for the minimum rights and amenities of the civil population. In fact, these activities are intended to facilitate longer term military operations. But for the commander there may be no long term operation if he fails in the immediate battle. ${ }^{38}$ As a result, civil affairs staffs were not fully accepted into the military hierarchy and were treated as 'quasi-civil poor relations'. The British army divisions, Donnison noted, contained some 'extremely able officers ..., with a sprinkling of regular soldiers. But many tended to be eccentrics, skilled in some little-known or faintly ludicrous employment, but hopelessly unmilitary, and some even anti-military. Or else, somewhat naturally, they were the weaker members rejected from the more active units. All Civil Affairs officers were likely to be a little elderly. A General Officer delivering an inaugural address at the Civil Affairs staff centre seemed to see seated before him all those officers whom he had, over the past months, been at pains to weed out from under his command. 39

Donnison did not discuss public health, but his observations also apply to this field. The records from American and British public health staffs show that their work suffered from a low ranking in the military hierarchy. Public health operations, especially those dealing with civilian populations, were widely seen as secondary considerations. Public health often fell into the gap between military and civilian authorities' responsibilities, as a result of which there were many overlapping agencies, but a shortage of officers and field personnel. ${ }^{40}$ The fact that the American Public Health Branch's request to be represented on the USGCC Planning Coordinating Section was turned down was symptomatic of its low status. ${ }^{41}$ Their representation was undesirable, came the response, because '[i]f such an officer were detailed for this field of secondary importance we could expect to be flooded by requests from special staff sections and the services who have much more legitimate pleas than the Medical Corps'. ${ }^{42}$ At exactly the same time, similar concerns were also expressed in British public health quarters. Brigadier E. W. Wade from the army's Medical Sub-Branch was 'very worried to see that Medical questions do not appear in any high level documents'; he thought 'that a Medical Representative should be present at all meetings of Planning Staffs on whatever level' ${ }^{43}$ Here, too, these demands were refused.

This problem of status is important for understanding how Allied staffs expected public health work to fit into the occupation. In organizational terms, responsibility for civilian health was given to the Public Health Branch of G5/SHAEF. Some work was also conducted within the Internal Affairs and Communications Division of the future Control Commissions. The British division was based in London and was active from 1944 onwards, but in the early stages was primarily concerned with the recruitment and training of its staff. The director of the British Public Health Branch was William H. Boucher. ${ }^{44}$ The corresponding American division was established in November 1944, and its Public Health and Welfare Branch was headed by Morrison C. Stayer. ${ }^{45}$ The work carried out by SHAEF and the two Control Commissions was supplemented by preparations by the British and American army groups who were about to move into Germany. In both, basic public health work was carried out by the medical officers in military government detachments. An American directive from April 1945 explained that these detachments

are military units which have prescribed missions, including public health activities. They are provided to relieve the fighting forces of civil commitments to the maximum practicable. Whenever possible they, like Military Government Staffs, serve as channels for dealing with civil authorities. Their primary objective is to stimulate the activities of indigenous personnel in reestablishing or maintaining medical and public health services, so that the military effort is not impeded, and 'will be the agencies of their respective Commanders to ensure that governmental authorities take the necessary measures for observance by the civilian population of any such policies laid down' ${ }^{46}$ 
Infectious diseases posed the most urgent threats. Army staffs were to prevent epidemics, especially of typhus and typhoid fever, by putting in place strict quarantine arrangements, reporting all incidences of disease, supervising vaccination programmes, and repairing sanitary installations. Instructions demanded that detachments were to make contact with native health officials and give assistance where necessary.

These health operations were very different from work that was overseen by the British and American civilian health departments in their countries, and from the activities by non-governmental or international relief organizations such as the Red Cross or the United Nations Relief and Rehabilitation Administration (UNRRA). There simply was no forum for non-military health work in Germany. The Health Organization of the League of Nations had more or less shut down by the outbreak of war in 1939; the Office International d'Hygiène Publique officially continued to operate throughout the war and relocated from Paris to near Vichy, but was not involved in practical health work among German civilians. UNRRA, although it was actively organizing medical relief on German soil, was specifically barred from assisting German citizens, or 'enemy subjects', and was restricted to the care of displaced UN nationals. ${ }^{47}$

It was for these reasons that British public health work in Germany was prepared within the War Office, not the Ministry of Health. The ministry's only involvement concerned the supply of medical officers: throughout the war, William Boucher, 'an experienced civil servant ${ }^{48}$, and his staff regularly approached the ministry and the Scottish Department of Health with requests for medical officers. Boucher asked whether they could recommend suitable candidates, and whether they could offer guidelines on the salary ranges to be adopted for these officers. He also asked for advice on how to advertise jobs and conduct job interviews. ${ }^{49}$ The ministry repeatedly replied by pointing to the shortages of medical officers they themselves were facing. 'This is a bad time for us', wrote the Scottish Department of Health on more than one occasion, and it would be 'very difficult for us to release any of our own men' ${ }^{50}$ These demands for the release of individual medical officers from their duties regularly provoked protests and complaints by ministry officials. They complained fiercely about how 'Boucher's army of medical officers ${ }^{, 51}$ interfered with public health and civil defence at home in Britain, and responded by dragging their feet.

The following episode illustrates the fractious relationship. In March 1945, just weeks before the British Control Commission's Public Health Branch was to commence its work in Germany, Mr Donelan from the Ministry of Health minuted that Boucher had approached him with a plea to help in the appointment of " "two or three" public health doctors'. 'I find this request a good deal more than I bargained for, in these days when public health doctors of quality are like gold', Donelan complained. It had made him wonder: " "If the Berlin section alone wants 'two or three' doctors, how many is the whole Commission going to want eventually?", 52 One of the men Boucher had asked for was the medical officer of health for Bromley, a Dr Kenneth Tapper. Donelan observed that Tapper was 'one of the best M.OsH. [Medical Officers of Health] in the London Region and occupies a key position in the Civil Defence Services and in Group 8 thereof and represents the Kentish Authorities on the Commissioners' Advisory Committee. Civil Defence alone would feel his loss very heavily. Moreover that area has had heavy inroads made on its P.H.Med Officers. ${ }^{53}$

Donelan and other ministry officials insisted that appointments to the Control Commission could only be made if public health provisions in Britain were guaranteed. As one official minuted, the problem 'rest[ed] upon whether the present [public health] staff could carry on either with or without part time assistants or with or without consultation with a neighbouring M.O.H. ${ }^{54}$ Another noted that it was 'a matter of appraisement as to which sphere of activity needs Dr Tapper most. If the Control Commission to Germany gets him they win a first class man \& we lose him. It would be a big price for us to pay', he thought, 'but taking into consideration the present war situation I feel we should foot the bill. ${ }^{55}$ Others argued that the problem had to be dealt with in general, not just in relation to Dr Tapper: 'The Control Commission is no doubt unaware of the extremity to which we have now come as regards public health medical staff, and appears to be seized of the idea (perhaps not unnaturally) that there must still be persons in this field on which it can reasonably draw for the ideal men required for the Commission's purposes.' However, this note went on, it was now 'desirable to dispel this idea, and to take the line, as things now stand, that there is no hope of finding any further assistance for the Commission among medical officers, who are now quite inefficient to meet the minimum needs at home'. ${ }^{56}$ Kenneth Tapper, who was decorated for his efforts to relieve suffering among air-raid victims in Bromley, does not seem to have made it to Germany. $\frac{57}{}$

This conflict was not just about the priority of home requirements, but the questionable entitlement of the soon-to-be defeated enemy. Why should British needs suffer because of Germany? A Ministry of Health official explained that it had been difficult enough to get local authorities to release their medical officers for civil affairs work in the 'liberated 
countries', who had 'a strong intrinsic claim' - and it was 'almost certain that there will be far greater difficulty in getting Authorities to release men for the benefit of Germany (which is how they will interpret such demand)' 58

Everywhere, the military's public health work was affected by personnel shortages and the low status of public health work. But the widely acknowledged 'serious dearth of medical practitioners' was here aggravated by the fact that public health work in Germany, in particular, was not perceived to be a priority. ${ }^{59}$ By late 1944, staffing for the German occupation had become a regularly voiced concern in public health quarters, and was discussed at length at a meeting of SHAEF public health officers from the American and British military groups in January 1945. Items on the agenda included problems such as the lack of equipment and transportation, the lack of time, and the lack of coordination with other sections of the military. But more than any other issue, they bemoaned the lack of suitable public health personnel. As the deputy of the Public Health Branch of SHAEF's G5 division, Colonel Wilson, stated: '[i]f we do not get the right distribution, public health operations will fail. We must keep plugging away.' Concerns about 'numerical shortages' were bad enough, they said, but '[a]ctual functional shortages are even more evident'. Participants also voiced their concerns about 'shortages in the British area, the fact that all officers in the American area are not qualified for public health work, and the fact that the current status has been presented to the Combined Chiefs of Staff. Reference was made to numerical shortages to show what we are up against in the matter of qualified personnel. ${ }^{, 60}$

The shortages were apparently acute. Colonel Crichton from the Twenty-First Army Group maintained that the British situation was 'extremely serious':

unless we can get better promise of personnel we require, it is impossible for me to accept the responsibility which has been placed upon me. I cannot do it without tools, and by tools I mean bodies. The planning I have committed to has been restricted to 10 medical officers per group. I have 16 present out of 80 authorized and 80 is the barest minimum by which we could succeed. This has been taken up here at SHAEF and at the War Office, but at home they do not realize how serious this matter is, and the fact that German health conditions, if not taken care of sufficiently, will boomerang on us and the Army in general. The matter should be stressed, and stressed very forcibly at this time. 61

Another commentator noted that the Ministry of Health was 'scouring the public health local authorities for the names of men who are willing to take the civil affairs test. The list is a fairly substantial one but of course, a number of people are unfit, some are not willing to volunteer, and there are people whom the authorities are not willing to release. ${ }^{62}$ It was not only the severe shortages in themselves, but the absence of qualified health staffs which proved to be of most serious concern. Since detachments and army groups were to shoulder the real health work, it was crucial to provide them with 'proper and enough people' who were qualified for public health work. ${ }^{63}$ Colonel Crichton hoped that 'when civil agencies are being requested to part with their men ... they do not think Civil Affairs is a refuge for the doddering ... but that we do need active men who are really good at their jobs' 64

\section{(ii) Liberated vs enemy countries}

Shortages of qualified personnel and the low status of public health were not specific to the German occupation, but here they were magnified by problems not shared elsewhere: not only were staff for Germany particularly hard to find, but health work was restricted by a distinction between liberated and enemy countries. A manual for Operation Eclipse, designed as the first stage of the peace and initiated as the Allied armies crossed the Siegfried Line, described this differentiation. In the liberated countries, it stated, 'we are dealing with our allies and it is only the accident of war that brings us into their country. We therefore respect their sovereignty and their institutions, and we endeavour to work in harmony with them. We do not interfere with their laws, nor attempt to impose any of our own; and we claim no jurisdiction whatever over their citizens. ${ }^{, 65}$ In Germany, on the other hand, it was

the duty of commanders to impose the will of the Supreme Commander upon the German people. The diplomatic approach to civil authority which is used in liberated territories will be replaced by the issue of orders, obedience to which will be exacted, and disobedience to which will be punishable in our own Military Government courts. The civil administration, and all aspects of civil life, will be directed and controlled according to the requirements of, initially, the Supreme Commander and, ultimately the Control Council, whose authority will be final. Germany will be made to realise that this time she has been well and truly beaten in the field by force of arms, and must now do as she is ordered. 66 
This distinction also applied to public health. Donnison put his finger on it when he described civil affairs work in Burma, where the officers 'were invested with a dual responsibility, to the military authorities for the bare prevention of disease and unrest, [and] to the Burma Office or to the Colonial Office to raise standards above this level, since the people of these countries were British subjects, and it was felt that they should be treated more generously than enemies'. ${ }^{67}$ By contrast, in Germany, 'generous treatment' was highly inappropriate, and security concerns determined the work of the health officers. Colonel Wade, a senior medical officer in the British Control Commission, inquired about the 'policy in respect of the issue of drugs which are potentially explosive, to German civilians and military medical services', particularly glycerine, iodine, sulphur, and certain potassium salts. His view was 'that [the Germans] should be made to use substitutes and that these should all be kept for use by the Allies, or be destroyed'. 68

Such a distinction between public health work in Germany and other countries was not inevitable. As we have seen, this distinction was absent in earlier schemes. The work produced by the Allied Committee on Post-War Requirements, the so-called Leith-Ross Committee, is a case in point. In a February 1942 paper on measures for post-war relief and reconstruction, the authors recognized that the difficulties of prioritizing 'among the conflicting claims, and unequal situations, of Allied, neutral and enemy countries, [were] clearly enormous'. ${ }^{69}$ They argued that ' $[t]$ he only hope of achieving rough justice in the allotment of priorities would be to regard Europe (or those parts of it to which we have access), so far as possible as a whole from the beginning. Even if "need" is referred to the barest necessities in food, clothing and medicaments, the acceptance of such a view will demand an important intellectual and moral effort of the more favoured peoples. ${ }^{70}$ Germany was here conceived as a necessary part of international relief efforts. 'When the present war ends', the paper stated, 'the needs of many parts of Europe will be more urgent than those of Germany, but she should also receive what is estimated to be due to her on the scale of need', with the addition that 'any political or financial conditions to her doing so should be settled beforehand' ${ }^{71}$ Relief work was to be determined by need, and the neediest countries were those which had seen the heaviest fighting. ${ }^{72}$ Finally, the Leith-Ross paper stated that, since 'the control of starvation and such diseases as may be expected after the war depends primarily on transport, economic reconstruction and agricultural recovery', it was 'from a health point of view ... essential to continue urgent relief work for sufficient time to enable a fair degree of economic and agricultural prosperity to be reached, probably over a period of some years'. 73

This and other papers did not distinguish in principle between Germany and other countries. However, these premises disappeared from later plans. After the Morgenthau controversy, schemes no longer focused on possible German needs, but rather on Germany's comparatively high pre-war standard of living. Similarly, the recommendation that public health required a level of economic and agricultural development clashed with later principles of what the occupation was to achieve: the aim was not to facilitate Germany's recovery, but rather to remove the German threat to world security. As a result, the link between the population's health and the country's prosperity was subsequently removed from occupation manuals.

In practice, health planning for Germany was very different from the Leith-Ross Committee's recommendations. One episode illustrates the tenor of the debate. In June 1942, Mr Gorvin from the Ministry of Economic Warfare wrote to the Polish Ministry of Finance that he was compiling estimates of the immediate post-war requirements of Germany, and wondered whether the Poles could help with data or ideas. ${ }^{74}$ Immediately a storm erupted, and colleagues noted that Gorvin had 'fairly put his foot in it with the Poles'. The Central Department of the Foreign Office expressed concern about likely complaints from other Allies, 'on the grounds that this is hardly the appropriate time to discuss the feeding and reprovisioning of Germans, seeing that we have not yet settled how to deal with the immediate needs of our own Allies. If such representations are made I think that the only line to take will be to say that Mr Gorvin acted entirely on his own initiative and that there is of course absolutely no intention on our part to commit ourselves in any way to proposals for feeding Germans before we have all made up our minds on the political problems involved. ${ }^{, 75}$ Several government departments stepped in to remedy the 'acute embarrassment ... caused by Mr Gorvin's action'. 76 Central Department tried to soothe worries: '[T]here is of course no justification', one official wrote, 'for putting postwar requirements of Germany at all high on our list of priorities and it would certainly be our intention to make certain that the main principles of essential relief for our Allies and for the victims of German aggression are formally established before devoting any considerable thought as to how to better the lot of the aggressor countries. 77

Britain's sometimes fragile relationship with the other allies was one consideration; another was that there was an apparent educational component to restricting the health and relief offered to Germany, as suggested by insights into the German national character and its limited potential for improvement. Some argued that for pedagogical reasons the Germans should be given food only after all the nations who had suffered because of Germany. ${ }^{78}$ As Henry Dicks, a 
British psychiatrist who was drafted to work for the British Control Commission in Germany, put it: from the 'psychological point of view', the 'manner of administering such relief as is contemplated will be important in influencing German attitudes. The rations should be kept below those of our Allies. ${ }^{79}$ This was a persuasive argument, all the more appealing at a time of shortages and supply bottlenecks.

As a result, health operations in Germany were to be conducted in a different tone from those elsewhere. Differences concerned particularly the provision of supplies and personnel — and since so many of the discussions focused on supply, this was crucial. American and British health officers were instructed to distribute food, drugs, and medical supplies first to liberated populations, and once in Germany, to Allied nationals and non-German displaced persons, before considering the requirements of the German population. Germans were not to be given any medical supplies beyond the absolute minimum necessary. ${ }^{80}$ The provision of supplies was planned differently for the two categories: 'For German civilians, planning [provided] only for basic medical units; for displaced persons, we have planned for basic medical units, $\mathrm{x}$-ray supply units, sanitation supply units, obstetrical bags, etc. ${ }^{81}$ In these terms, Colonel Scheele from SHAEF's Preventive Medicine Section observed that ' $\mathrm{t}]$ ]he general medical supply program for Germany is not too generous, but the program is adequate for communicable disease control. The first effort will be to utilise German biological and other medical supplies. ${ }^{82}$

Even more urgent than medical supplies was the supply of food. Allied troops were instructed to ensure a daily allocation of 2,000 calories per person in the friendly countries and for those non-Germans in the displaced persons camps in Germany, mainly by using up military stocks and distributing donations and German stores. On the other hand, in the light of prevalent shortages rations for the German population had to be significantly lower. 'The feeding of the Germans was going to be a difficult one', Colonel Hermann thus noted in January 1945, particularly since ' $[\mathrm{t}]$ here will be no imported food issued to the German population except in extreme emergencies'. ${ }^{83}$ Colonel Wilson made this point most bluntly. Speaking about the allocation of food supplies, Wilson asked: 'The question is, how much can you cut the German down and keep him breathing. How much do we dare cut him down?'

\section{(iii) Public health plans for Germany}

Let us briefly examine two particular plans for public health work, which were ready just before the end of the war. First, the Twenty-First British Army Group drew its instructions about public health work from the 'Eclipse Medical Outline Plan'. The plan predicted that the public health problems in Germany would be similar to those already encountered by troops in the advance from Normandy to Brussels, "with the important difference that the operation will take place in hostile enemy territory and there can be no reliance on the co-operation of the civilian population' ${ }^{85}$ It anticipated that destruction and economic conditions were 'likely to be much worse than anything we have yet experienced', and it was 'essential that all Hygiene [officers] should have a plan to work on'. ${ }^{86}$ Major problems demanding health officers' attention, it suggested, were the control of infectious diseases; arrangements for hospital accommodation of displaced persons and refugees, and emergency beds for epidemic outbreaks; and the restoration of water and sewage systems and the civilian laboratory services. 87

However, despite this, practical assessment health work was limited by the premises of Allied occupation policy. The plan thus emphasized that health work must not exceed the bounds of 'military necessity'. It differentiated between health work in liberated countries and in Germany. And it spelled out that in Germany, the officers' primary task was the maintenance of health among the occupying forces and displaced persons. 'The hygiene task is likely to be immense', it stated, but 'it will not be possible to meet all demands, and we must, therefore, in the first place, concentrate on essentials.'

(a) The first concern is and remains the health and prevention of disease in the British Armed Forces.

(b) Secondly, concentration on our own and Allied PW.

(c) Thirdly, there must be insistence on reasonable Hygienic standards in German concentration areas, and

(d) Fourthly, everything possible must be done to reestablish, at the earliest possible time, civilian health services. ${ }^{88}$

Because the existing German authorities were to continue to administer health services, only one short section of the plan considered hygiene measures for the German population, while twelve sections concentrated on medical care for Allied forces and UN displaced persons and prisoners of war. Instead of preparing for epidemics and health crises, health teams were told to focus on the collection of information on German equipment and medical stores, through 
which the requirements of Allied purposes elsewhere were to be met. ${ }^{89}$ In April and May of 1945 public health officers involved in the Eclipse Plan met in the context of a working party to examine the 'long term medical policy for Germany', and their primary concern was the examination and stocktaking of German medical material, personnel, and installations for uses elsewhere. ${ }^{90}$

A second example is the Bavarian operational health plan, produced by an American detachment in April 1945. The plan began with an overview of the German regional and local organization of health administration and the role performed by the German Ministry of the Interior. It went on to anticipate the kind of situation likely to be faced by the American health staffs. 'In the event of danger of spread of communicable disease beyond the borders of Germany,' it spelled out, 'emergency measures beyond those prescribed by the International Sanitary Convention may be taken', if absolutely vital. ${ }^{91}$ But apart from these emergency scenarios, 'the Public Health functions of Mil Gov' would be limited to:

(1) Control of communicable diseases among civilians which might affect the health of Allied troops. This necessitates a responsible civilian health organization, properly equipped and staffed with suitable facilities and powers to carry out its necessary functions.

(2) Provisions of medical care necessary to protect the health of United Nations Nationals in Germany. This necessitates provision of medical staffs, facilities and services for these people.

(3) Utilization of German Medical and Public Health resources and productive capacity to the extent needed to supply urgent needs of the United Nations, and to allow the balance to be used for maintenance of public health in Germany.

(4) Removal of active Nazis and ardent Nazi sympathizers from German public health services, and their replacement by acceptable personnel. ${ }^{92}$

Just weeks before the end of war, both plans limited public health operations in Germany to ensuring the success of military operations and the protection of the health of the occupying troops and UN nationals on German soil. Civilian health did not feature as a major concern, because German authorities were expected to continue with their work, and Allied health officers were only required to supervise them.

Directives on the treatment of Germany after its surrender thus had a clear impact on public health work. They had developed the notion of a 'hard peace'; they had presented the health system as an extension of the German war state; and they demanded that Allied officers were not to show any sympathy for German suffering. Health officers were instructed that, in the interests of security and justice, German living standards and nutrition were to be capped at levels below those of neighbouring countries. The main effect was to limit health work. While public health work carried out by army detachments usually involved making contact with the native population and combining army and civilian resources, it was to be much more limited in Germany.

Four related premises shaped the preparations for British and American troops' public health work. First, the notion of 'military necessity' served to remind health officers that the main focus of occupation policy was the defeat of Germany, the eradication of Nazism, the punishment of those responsible, and the freeing of forces for operations in the Pacific. Health operations on German soil were necessary only so far as they affected Allied troops and Germany's neighbours. Supplies were to be confined to 'a minimum necessary to prevent disease and such disorders as might endanger or impede military operations' ${ }^{93}$ Health officers were to 'plan and coordinate the provision of resources for prevention and control of disease among civilians or animals which might interfere with military operations' and to 'assure availability for distribution of medical supplies necessary to prevent or control diseases which might affect or interfere with military operations or health of the troops' 94 'Military necessity' thus defined the purpose, reach, and objectives of occupation public health programmes in Germany.

Second, the occupiers were to rely on German organizations for the bulk of necessary tasks. According to the principle of 'indirect control', which stemmed from British experiences with its colonies, Allied officers were to supervise and control German health authorities indirectly, without actually doing any of the necessary work themselves. ${ }^{95}$ The plans for the British and American public health branches were based on the assumption that the Allies would issue directives to a central German government, and that the Internal Affairs and Communications Division would control and supervise the German Ministry of the Interior. ${ }^{96}$ When in January 1945, General Draper asked whether 'the Germans [will] actually do the work in the field?', Boucher explained: 
Yes. It will be the Military Government officers who will be controlling each Public Health department at Provinz level. Our relationship is with the Ministry on top and does not extend beyond that. The rules for dissemination of instructions have not been worked out as yet, but possibly we, on behalf of the Supreme Command, will give directions to the German Ministry for the issue of instructions on this matter down to those in the field, and it will be for the Military Government officer in the field to see that those instructions are duly acted upon, and are effected. We are planning on the assumption that central government in Germany will still exist.

'We have no intention of assuming any executive responsibility,' he added. 'Our job is to control them, not to do the work for them. 97

As a result, planners allocated only limited supplies and personnel, and assumed that the German authorities would to continue to work without interruption while denazification was in process. The inherent contradiction was only rarely acknowledged. In September 1944, when the UK Treasury was in the process of approving the sizes of various Control Commission branches, a Treasury official, Mr Wilcox, inquired about the extent to which the British authorities were going to interfere with medical and health arrangements in Germany. 'I can see that in the early days there will need to be a pretty close supervision to guard against epidemics in the chaotic conditions that may exist', he wrote to Boucher, 'but one would have thought, prima facie, that after this initial period the health services would be essentially a thing which the Germans in their own interests would want to run as efficiently as possible. ${ }^{98}$ In reply, Boucher argued for some need of regimentation. 'I agree that the administration of their own health services is something which we can ultimately rely on the Germans to run for themselves on efficient lines with a minimum of oversight on our part' - but, he added,

How soon they can be left to do so is entirely conjectural. We do not know in what condition we shall find the administrative machine, but one thing, to my mind, is quite clear: Nazi doctrine permeates the whole public health structure and must be eradicated. If control amounted to no more than this, its result would undoubtedly be to eliminate the severe regimentation to which the health services and their personnel are at present subjected. These services cannot, however, be permitted to function on purely parochial lines, in face of the many public health problems likely to confront us for a considerable time after the cessation of hostilities. Regimentation of a fairly strict kind will be essential, and it will be our job to enforce it. ${ }^{99}$

Nevertheless, when a month later Boucher listed the future duties of his senior staff, these tasks were those of administrators and overseers, not those of health officers who were going to get at all involved in any practical public health work. 100 The fact that large sections of the German health service had joined the Nazi Party and would now need to be removed, was also asserted by other sources. As Brigadier Wade, senior medical officer of the British Control Commission, noted in May 1945: while 'the Political Investigators have not got very far with the identification of Medical Officers by Political creed', he thought that it was 'the opinion of the Political Intelligence Dept. that a very high proportion of the Medical Officers are Nazi' ${ }^{101}$ But if indeed 'Nazi doctrine permeates the whole of public health structure', exactly who the Allies could supervise and control was not spelled out. Not only were the terms of 'ardent sympathisers' and 'active Nazis' vague, but many schemes also assumed that, while Nazi public health laws obviously had to be annulled, most existing laws and health arrangements could remain in force unaltered, since they were 'sound in most instances'.102

By late 1944, a third premise of preparations for the German occupation concerned the concept of a German standard of living - an assumption which only appeared in this form in the later stages of the war. The 1942 Leith-Ross paper had still noted as a matter of fact that the most extensive health and relief operations would have to be conducted in countries where the heaviest fighting had taken place, Germany included. But this notion disappeared after the Morgenthau episode, supported by planners' belief in the ultimate efficiency and superiority of the German health organization.

The United States Strategic Bombing Survey's study The Effect of Bombing on Health and Medical Care in Germany, compiled during the last year of the war and published in autumn 1945, exemplified this perspective and its contradictions. In close to 400 carefully researched pages it laid out how German health and medical care had been severely disrupted by the war. It did not mince its words on effects and consequences: although it found 'no evidence of Allied effort to break the health of the German people', it showed unequivocally that the bombing had 'succeeded in greatly lowering the standard of health throughout Germany by destroying facilities for the maintenance of environmental sanitation, by creating the most acute conditions of overcrowding which have been encountered in the 
western world, by denying civilians hospital care and adequate drugs, and by changing three meals a day from an individual habit to an object of individual ingenuity'. In effect, 'the average inhabitant of the German cities was placed in the same position as the soldier in the battle field'. And yet, such observations did not prompt a reconsideration of the problems to be encountered by the occupation troops. On the contrary, its conclusions pointed to the fundamental strength and soundness of German structures. '[T]he one outstanding fact which the study of these data defines', it maintained, was that 'a people well trained in personal hygiene, who ... know where the dangers to ill health lie, are the strongest bulwark against breakdown of public health when their cities have been destroyed by the enemy.' Even a 'democratic society' such as the United States could usefully learn about how 'a thoroughly regimented nation reacted to air raids', and how it could thus 'rise to a similar threat in the future'. 103

Such observations signalled to health planners caution in designing programmes that were 'over-generous' ${ }^{104}$ Public health measures had to be 'adequate' for the protection of troops and neighbouring countries, and nutrition teams had to ensure that food supplies did not exceed minimum levels. ${ }^{105}$ From autumn 1944 onwards, British and American planners often overestimated the conditions they expected to encounter in Germany. They no longer contemplated that the German standard of living might actually have to be raised because of extensive destruction. As late as January 1945, Colonel Wilson was optimistic that 'Germany has maintained a good status of public health, and more than likely, we are going to be able to accomplish the same thing ... we must accomplish at least as much' ${ }^{106}$ The inherent contradiction between maintaining a basic standard of living at the same time as deindustrialization and demilitarization were in process only became fully apparent after occupation began. ${ }^{107}$

Finally, a fourth premise in occupation plans stemmed from conclusions about the German mentality and the expectation that the Germans would attempt to trick or corrupt Allied officers by spreading pro-Nazi, pro-German, militarist propaganda. Perhaps the most important result was the 'non-fraternization' rule, which prohibited Allied troops stationed in Germany from maintaining any personal contacts with the German population. By early 1944, instructions informed troops not just about the 'mission of the occupying forces', but also about the 'characteristics of the German people, their probable attitude towards the forces of occupation and the type of propaganda which they are liable to employ'. ${ }^{108}$ A formal non-fraternization rule was the logical next step. The 'avoidance of mingling with Germans upon terms of friendliness, familiarity or intimacy, whether individually or in groups, in official or unofficial dealings ${ }^{109}$ was to guard occupation officers against Germans' attempts at persuading them of their innocence, and to avoid situations where they would be overly exposed to the German plight. Even shaking hands with the Germans was prohibited, since, as one instruction explained, to " "shake hands on it" is commonly accepted as "burying the hatchet". Broadly speaking, in civilized communities it signifies a token of friendship. The Germans will endeavor to shake hands on every possible occasion in an attempt to curry favor. Drinking with Germans, visiting German homes, playing games or taking part in sports with Germans and accepting or giving gifts, is not permitted. German women will be treated with courtesy but behavior towards them is to be strictly governed by the policy of nonfraternisation. ${ }^{110}$ Those who had studied the German national mentality saw non-fraternization as an important protective mechanism, but in practice it was to create problems, particularly for the Allied health teams, who had not only to work closely with their German colleagues, but also to tackle the products of their fellow occupiers' violations of the ban, namely venereal diseases and unwanted pregnancies.

\section{The other two? Soviet and French approaches to the Occupation of Germany}

Preparations for the Allied occupation of Germany in Washington and London created the blueprints not just for the British and American zones but for the entire occupation of Germany. They bound the other two occupiers, the Soviet Union and France, to priorities they did not always share and arrangements they did not always support. Both Soviet and French attempts to develop plans of their own were hampered by internal disagreements over aims, a lack of resources, and, most acutely for the French, a lack of time.

\section{(i) The Soviet Union}

Soviet plans built upon the main principles for the treatment of Germany agreed at the wartime conferences: after defeat, Germany would be demilitarized, its industries decartelized, and its institutions and public life denazified. However, the Big Three's public accord disguised discord behind the scenes. Soviet policy prioritized military and economic security in a manner frequently distrusted or openly rejected by the British and Americans, particularly in matters of reparations. In view of the devastation of large parts of the Soviet Union, the Soviet government was determined to demand the payment of a huge reparations bill. In a proposal presented at the Yalta conference, Stalin called for German reparations of $\$ 20$ billion, of which $\$ 10$ billion were to go directly to the Soviet Union. ${ }^{111}$ They 
were to come from a variety of different sources: dismantled German industrial installations, direct deliveries of goods from current German production, and German manpower. The Morgenthau Plan, although not implemented, marked a shift within Anglo-American thinking to a more tough-minded handling of Germany. By contrast, there were clear economic reasons why the Soviet Union supported proposals to deindustrialize Germany. Later, at the Nuremberg Trials, Roman Andreyevich Rudenko, chief prosecutor of the Soviet Union, presented staggering figures of damage, loss, and destruction as part of the Soviet Union's case against the Third Reich. He maintained that 679 billion rubles of damage had been caused as a result of the war, and 1,710 towns and 70,000 villages had been completely or partially destroyed, as well as 6 million bridges, 65,000 kilometres of railway tracks, over 100,000 farms, and 40,000 hospitals. At least 25 million people had been made homeless and 88 million Soviet citizens lived under occupation. His estimates went down to the last heads of livestock: 7 million horses, 17 million cattle, 20 million pigs, 27 million sheep, 110 million poultry had been killed or stolen. 112

By the time Rudenko presented this evidence, Soviet planners, economists, and politicians had been compiling estimates of damage and calculations on reparations claims for several years. One of them was the Hungarian-born economist and communist theoretician Eugen Varga — director of the Soviet Academy of Sciences' Institute for International Economics and Policy, and secretary of its Department of Economic Science and Jurisprudence, and, in the words of one West German scholar, 'one of the most significant and influential economists in the Soviet Union' 113 Throughout the war, Varga prepared papers and reports on subjects such as the economic consequences of total mobilization in Germany, the Third Reich's exploitation of the countries it occupied, and the post-war legacy of Hitler's new order in Europe. ${ }^{114}$ Soviet reparations policy began to take shape in a series of publications and memoranda Varga composed for the People's Commissariat for Foreign Affairs. In early 1942, he presented the basic premises of Soviet policy in a paper entitled 'Lessons from the First World War'. ${ }^{115}$

In a September 1943 report addressed to Maxim Litvinov, the former Soviet ambassador to the United States and then deputy foreign minister, Varga examined the economic consequences of divisions of German territory into three, four, or seven separate states. Each scheme, he concluded, would lead to the substantial weakening of Germany's - and particularly Prussia's - military and economic potential. ${ }^{116}$ His conclusion was that reparations programmes would have to be comprised of German industrial installations, to be rebuilt in the Allied nations by German labourers. In addition, the Soviet Union should receive income from current industrial production and raw materials. Where Morgenthau had concluded that German industry would have to be dismantled not simply to prevent another war but also because of justice and pedagogy, Varga and other Soviet economists saw reparations as a means for rebuilding the economies of Germany's former victims, above all that of the USSR. This was a crucial difference. ${ }^{117}$ Apart from material reparations, Soviet planners also saw the occupation as a means to acquire German military technology and scientific knowledge for application at home. It was clear from the beginning that German resources were to provide for the maintenance and upkeep of the Soviet troops on German soil.

These pillars of the Soviet Union's agenda — security and Soviet economic recovery—were explicit enough, as was the fact that public health among the Germans did not rank highly (or, indeed, at all) in this project. But matters were complicated by the sheer variety of politicians and government institutions which took an interest in Germany. Just days after the German invasion of the Soviet Union in June 1941, the chief of the Red Army's Political Administration instructed the newly created Soviet Bureau for Military Propaganda to begin preparations for the aftermath of the war. The bureau was staffed with renowned individuals such as the former secretary of the Communist International, Dimitry Manuilsky; the deputy people's commissar for foreign affairs (under Vyacheslav M. Molotov), Solomon Lozovksky; the head of the People's Commissariat for Foreign Affairs' press department and from 1943 director of the Soviet news agency Tass, Nikolai Grigoryevich Palgunov; and Eugen Varga. $\frac{118}{2}$ From 1941, and with renewed vigour after autumn 1943, the bureau examined various problems of the post-war occupation, for example by studying the British and American occupation of Sicily. ${ }^{119}$ In parallel, a number of technical departments of the Soviet Communist Party's Central Committee worked on similar questions, also directed by the Red Army's Political Administration. Individual ministries of the Soviet government also set up their own committees and planning staffs. During 1943, the People's Commissariat for Foreign Affairs created three specialist commissions on the problem of post-war Germany: one, headed by Maxim Litvinov, worked on 'war aims' and prepared for the peace settlement and post-war order; a second one, headed by Marshall Clement Voroshilov, former commander of the north-western front, prepared for the terms of the armistice and German capitulation; while a third commission, headed by Ivan Maisky, the former Soviet ambassador to Great Britain, prepared for matters of reparations and the dismantling of German industry. Together, these various bodies and commissions provided the means for politicians to begin to stake out their interests in the occupation of Germany. But there was little or no coordination between the ministries and the Bureau for Military 
Propaganda, or between the different ministries themselves - and many of their preparations were not widely read or distributed beyond the circles of their authors. ${ }^{120}$ There was no coordinating authority able to mediate between them.

And for many future occupation problems there were simply no preparations or instructions whatsoever. That quickly became a subject of concern and complaints. In December 1943, Andrei S. Smirnov, former Soviet ambassador to Iran and then head of the Foreign Ministry's third European Department, warned that the absence of clear instructions for the conduct of the Soviet military in the occupied territories could lead to catastrophic mistakes and miscalculations. He remembered from his time in Iran, he wrote, that the Soviet army leadership had not been familiar with 'local particularities, customs and conventions, state and administrative structures, legal regulations, and so on'. The situation would be little better in Germany, Hungary, or Romania. 'We know only very little about the organisational structures of the administrative system in Germany', he noted, nor about its 'tax system and agricultural levies arrangements, price policy, local supply of the population, structure of ministries, banks and other organisations'. It was necessary to compile information dossiers and handbooks on Germany, produce maps, compile lists of local facilities and businesses, and familiarize officers with the local administrative organs, the Nazi Party, the German army, and other organizations. All this was urgent, he added, because the war was already moving into its last decisive phase. Since the occupation of Germany involved extensive negotiations between the three occupying powers, Soviet military leaders would have to come prepared for 'complicated diplomatic discussions' requiring detailed knowledge of conditions, and the Foreign Ministry's diplomatic apparatus had to be ready to assist the military authorities. He suggested that members of the People's Commissariat for Foreign Affairs who had worked in Germany in the past should now be recruited for occupation duties. ${ }^{121}$ Half a year later, Smirnov complained again that guidelines for the selection and training of personnel for the occupation had still not been produced. ${ }^{122}$ By autumn 1944 the training of Soviet specialists for the occupation had evidently still not begun. ${ }^{123}$

To make up for these deficiencies, Soviet analysts studied British and American press reports, transcripts of speeches, memoranda, briefings, policy instructions, and reported conversations with Western leaders - both to track approaches hostile to, or in contradiction with, those of the Soviet Union, and to identify practices and policies which could be copied. ${ }^{124}$ Smirnov thought an analysis of previous British and American military occupations could assist Soviet preparations. 'I have to say that we have no experiences in this area', he noted, 'whereas the [Western] Allies already possess a well-rehearsed system, with roots going back to the previous war. They have people who carried out the military administration of enemy territories after the defeat of Germany in 1918. ${ }^{125}$ When the EAC suggested that the Soviet government dispatch ' 45 to 55' Soviet officers to London to take part in joint Allied preparations, Soviet officials saw this primarily as an opportunity for their personnel to study and familiarize themselves with AngloAmerican methods, systems of training, and concrete policies. ${ }^{126}$ Some Soviet instructions therefore drew explicitly on Anglo-American documents and duplicated their premises. When the Americans agreed in late March 1945 to give their military government handbooks to the Soviet authorities, ${ }^{127}$ a number of SHAEF guidelines found their way into Soviet instructions to their troops. Beria's recommendations in April 1945 for the organization of a military administration for civilian affairs essentially restated SHAEF's instructions to use existing local German administrations for matters of police, law, finance and tax, and other local problems such as public health. ${ }^{128}$

The Soviet readiness to copy Anglo-American approaches meant that the premises underlying future public health work also extended to the Soviet zone. At the same time, however, gaps and shortcomings in Soviet plans were filled by very different preparations, namely by those of exiled German communists, whose plans for post-war Germany were conducted under the direction of Georgy Dimitrov. Dimitrov had been secretary-general of the Comintern, and after its dissolution in 1943 became chief of the Soviet Party's Department of International Information (known as the 'foreign department'). In both capacities, he coordinated the work of foreign communists in Moscow. In spring 1944, Dimitrov instructed the German communists in exile to prepare for vital questions of post-war Germany, while his Comintern colleague Dmitry S. Manuilsky took over the training of German POWs. By March 1945, the German communists had drawn up guidelines for future political work in Germany, using Soviet information. These guidelines, sent by Dimitrov to Molotov, proposed that German antifascists were to accompany the Red Army and assist its progress through newly liberated areas by calling on German troops to surrender and urging the population to cooperate. They were to assist Soviet officers in the administration of urgent work such as the clearing of rubble, epidemic control, the revival of radio and newspapers, and the appointment of local officials.

\section{(ii) France}

In France, disagreements about different strategies centred around the different weight that should be given to shortterm economic exploitation and military toughness on the one hand, and longer-term efforts to reform and reintegrate 
Germany into the world, on the other. Popular French analyses of the German menace concluded that Nazism had been able to rise due to the inadequate post-war settlement of 1919, which had not gone far enough or imposed sufficiently serious measures on Germany; in subsequent years the original demands for reparations had been dropped completely, and the German war-spirit allowed to grow unimpeded. The Second World War was evidence not only of chronic German aggression, but also of British and American failure to contain it. Among France's politicians those who insisted on permanent German disarmament, and those who emphasized reform and reconciliation instead, could agree that the occupation provided a means to guarantee future French security and aid the reconstruction of France. These two priorities were often closely linked: both required a strong France, militarily and economically, and a weak Germany. A group of French advisers pointed out at a Chatham House study group meeting on post-war reconstruction that 'Europe would not be safe' as long as 'a country with a population of sixty million, vast industrial resources and an apparently permanent impulse to aggression remained in the centre of Europe' ${ }^{129}$ Finding ways to render Germany incapable of fighting was central to any French plan for the economic rehabilitation of Europe. ${ }^{130}$

But although they overlapped, the security focus and economic considerations soon produced diverging, even contradictory, approaches. French security demanded disarmament and the dismantling of installations, a division of the country into zones, and the decentralization of its political structures. But French economic interests required German industry to continue to produce raw materials and goods, and the four zones to be treated as an economic unit. Initially, many insisted that security had to come first, but the economic rationale was strengthened when in early 1945 a number of authorities compiled estimates on French losses and minimum compensation levels. The French Ministry of Reconstruction and City Planning calculated in January 1945 that between 1,200,000 and 1,500,000 buildings had been destroyed or damaged since the outbreak of the war (compared to 927,000 during the First World War). ${ }^{131}$ At a session of the French Consultative Assembly a few months later, experts estimated that the cost of clearing the wreckage and rebuilding houses, industrial plants, and enterprises would be around 1,236 billion francs. ${ }^{132}$ In August 1945, a special French commission revised these estimates upwards, and calculated that the cost of war and occupation damage amounted to a staggering 1,832 billion francs. ${ }^{133}$ Another influential report, compiled by a member of the French Consultative Assembly's Foreign Affairs Committee, P. O. Lapie, estimated reconstruction costs at 2,500 billion francs, and some experts thought that the real costs would be closer to 3,000 billion. ${ }^{134}$

Nor did it end there. Some economic experts pointed out that France had propped up the German war economy for four years. Apart from physical destruction, financial burdens stemmed from the maintenance of armies in the field, demographic losses, forced exports and German requisitions, pillage, and looting. Until 1944 France had supplied the German population with goods - partly funded through occupation charges (set in August 1940 at 20 million Reichsmark a day), and partly paid for in occupation currency, which was, as one of the French zone's historians, F. Roy Willis, notes, 'a worthless paper money whose ultimate backing fell on the French taxpayer'. ${ }^{135}$ Over 700,000 French workers had been sent to work in Germany. ${ }^{136}$ These figures led to widespread agreement that France had to seek reparations and compensation. From this priority came other conclusions: after defeat the Germans would pay the costs of the Allied occupation, and the French zone's economy would have to be developed so as to be of maximum benefit for French economic requirements. Precisely what would be of greatest use for French reconstruction (acquisition of German resources and dismantled installations, or continued German production) was not spelled out at this stage, which helped to obscure the contradiction between demands for the decentralization of German political life and the centralization of its economy. ${ }^{137}$ Public health work would be caught directly in between.

During the planning stage, France, more than any other occupying power, suffered under time pressure and lack of representation at key moments of Allied decision-making. Lucius Clay, Eisenhower's deputy military governor, later thought that 'the German problem as it then stood, originated in international conference', ${ }^{138}$ but the French had been absent at all the major wartime conferences. They were not present at the meeting of Roosevelt and Churchill in August 1941, which resulted in the Atlantic Charter. They had not participated in discussions at Moscow in autumn 1943, which was, according to William Strang, 'perhaps the most fruitful of all the international ministerial conferences held during the war'. ${ }^{139}$ As a result, France also missed the early days of the EAC. It was not represented at the Teheran conference in winter 1943, which planned the second front, or at the meeting of Roosevelt and Churchill in Quebec in September 1944. France did not take part in the Yalta conference in February 1945, which finalized many details on the future occupation, including the fact of a French zone. By the time France entered proceedings, all the important decisions had already been made. And in spite of de Gaulle's proclamation that it would be 'a grave error' to make decisions about Europe without involving France, ${ }^{140}$ France was not invited to the Potsdam conference in July 1945. This exclusion had lasting effects: not only was it 'a bitter blow to French pride', but it also produced a situation where a member of the ACC did not consider itself bound by Potsdam decisions and did not recognize the policy on 
which the Council was to operate. ${ }^{141}$ The ACC could only act by the unanimous consent of its four member delegations, and this quickly produced an unbridgeable rift between France and the others, as French leaders successfully vetoed the creation of central administrative agencies for Germany. ${ }^{142}$

Preparations for the occupation of Germany thus began much later in France than they did in Britain, the United States, and even the Soviet Union. When American and British planners first met to draft plans, the French were preoccupied with their own affairs: following the French military defeat, the vote by the National Assembly, and the assumption of power by Marshal Pétain in July 1940, France itself had become a divided and occupied country, formally partitioned into a northern zone, occupied by the Wehrmacht, and an unoccupied 'free zone' in the south. Although the Vichy government's civil jurisdiction officially extended over both areas, in practice it proved difficult to assert its authority and maintain its sovereignty from the German occupiers, until in November 1942 even the southern zone was invaded.

The years between France's fall in 1940 and its liberation in 1944 were not simply a problem of external aggression or foreign occupation. The Vichy regime drew upon considerable domestic support, and it represented, in some ways, the latest manifestation of long-standing internal French antagonisms. In his study of European fascist movements, the sociologist Michael Mann observed that by 1940 France, like Germany, had seen decades of struggle between democratic and authoritarian forces. 'The main prewar protofascist theorists (Maurras, Barrès, Sorel) were French,' Mann points out, 'and France had the largest interwar authoritarian parties of both right and left in the northwest [of Europe] ... Had the election due in 1940 been held (and in peacetime), the quasi-fascist PSF might have won over 100 parliamentary seats. ${ }^{143}$ Support for authoritarian or fascist movements was far from the only fault line dividing French society. Throughout the Vichy regime's existence and for years after its demise, French citizens were fiercely divided between republicans and anti-republicans, collaborators and resisters, members of the army and resistance fighters, aristocrats and class warriors, between the political Right and the Left, supporters and opponents of a managed economy, anti-religious forces and Catholics, Protestants, and Jews. The French political landscape reflected and enshrined these factions for decades to come, and gave rise to frequently clashing priorities and conflicting demands for control over the occupation of Germany.

Only after June 1944, when the Germans were ousted and the Vichy government was driven into exile, could France begin its ascent to the realms of Allied diplomacy, and eventually turn from an occupied into an occupying power. ${ }^{144}$ Suddenly things were happening at great speed. Paris was liberated in August 1944. During the following weeks, as the Allied armies liberated much of French territory, de Gaulle built his provisional government and created or reformed the ministries which would tackle, among many other issues, France's military strategy and foreign policy. His stubborn insistence on France's involvement in world affairs soon saw some major successes. Until the autumn of 1944 French participation had not featured in Anglo-American plans for post-war Germany, but by November France had obtained both a seat on the EAC and a promise of a share in the occupation. Before the year was out, recruitment began for the first military government teams for France's German zone, ${ }^{145}$ even before the territory to be occupied by France was formally agreed.

French participation in the military government of Germany only became a matter of fact in autumn 1944, when Eisenhower and SHAEF began to plan for French troops' participation in the attack on Germany. Initially, French personnel were to participate in military government detachments under American and British command. But by October 1944, SHAEF's plan for military government operations built on the assumption that French forces would be responsible for military government in the areas occupied by them, and that their detachments would be under French command. This revision presented another victory for de Gaulle's efforts to expand France's role in the occupation. As one American historian put it, SHAEF's G5 officers feared that 'any proposal to deprive the French of the power to command would lead to violent reactions'. ${ }^{146}$ France was still not formally allocated its occupation zone until February 1945, just three months before the end of the war.

De Gaulle's provisional government took its first concrete steps in occupation matters with the creation of the Military Mission for German Affairs (Mission Militaire pour les Affaires Allemandes, MMAA) in November 1944 - an office directed by General Koetz, but directly responsible to de Gaulle, charged with both representing French interests on the Allied High Command and liaising between the different French ministries. These first preparations focused almost exclusively on personnel and recruitment. Under Koelz's leadership this office recruited officers for the French Administrative Corps for Germany (Corps d'Administration Militaire Française en Allemagne, AMFA), and by the end of 1944 had put together the first contingents. AMFA's frustrations about recruitment at a time of acute personnel shortages mirrored those encountered by the other occupiers. Because the ministries insisted on keeping qualified and 
competent staff in Paris, the military administration soon filled up with lower-ranking officers and with old retired officials of questionable abilities or dubious political pasts. ${ }^{147}$

In the absence of clear French instructions, and with little time to prepare, the French military relied heavily on American and British preparations. In their training of staff, the French immediately asked SHAEF for assistance. The French School of Military Government opened at the Sorbonne in December 1944, where American and British officers, together with French academics such as Edmond Vermeil, taught short courses on German history, geography, politics, and psychology, and occupation policies. ${ }^{148}$ Just like their colleagues at the CATS in the US, many of those who taught here later occupied military government posts in Baden-Baden, including Charles J.Furby, later general director of justice, and the radical politician Jean Filippi, who had been chief of the Financial Department under Pétain and became director general of economy and finance. ${ }^{149}$ By 30 December 1944, 218 French officers had graduated from the School, and 27 Americans and 13 British officers had taken part in their training. ${ }^{150}$ Some French occupation personnel also attended courses on German language, history, culture, and economy at the Centre d'Études Germaniques in Strasbourg. 151

Throughout this time and well into the beginning of the occupation, instructions to French officers remained very sparse. One of the few guides available to French personnel was the SHAEF Handbook for Military Government in Germany, initially only in English, until a French translation was completed in December 1944 and published in March 1945. 152 Concrete French directives on general occupation policy only appeared months after French troops had already begun their occupation duties, when the Comité Interministériel des Affaires Allemandes et Autrichiennes (CIAAA) issued its first instructions to General Koenig in late July 1945, and even then French officers were bound by the priorities, inconsistencies, and contradictions of the SHAEF manuals.

\section{Conclusions}

The moral fronts were clear as the British, French, Soviet, and American troops made their way into Germany: it was in the interests of the peaceful and peace-loving nations that the Nazi regime should be defeated, and that after defeat, an occupation by the victorious wartime partners would ensure the eradication of any lingering remnants of Nazism, whether ideological, economic, industrial, or structural. German military and industrial capacities would have to be restricted, and German society would have to be cleansed and forcibly steered towards a better, peaceful, 'democratic' path. Throughout the planning period, probable areas of conflict and potential blemishes on this moral certainty were kept to a minimum.

At first policy stemmed from an early default level of preparations, based upon the assumption that Germany was fundamentally like any other country about to be occupied; after the Morgenthau debate a more considered 'hard peace' developed, based upon widely shared views of Germany and the Germans, but stopping short of the US Treasury secretary's recommendations. Late in the day, the Soviet and French authorities attempted to develop their own procedures, guided by their security and economic priorities.

As the Allied troops entered Germany, the public health problem raised a number of issues that were morally and politically not nearly clear-cut. The problem of how epidemic work could proceed within a population under foreign occupation, with whose resources and under whose control, was not adequately solved. Other contradictions also remained. The notion that Allied supplies to Germany were to be strictly limited and that the overwhelming burden of work was to rest with existing authorities was accompanied by a conviction that German society, and its health service, should be thoroughly cleansed of Nazi influence and personnel. The inherent clash between the decision to assign the overall responsibility for epidemic work to German doctors, and to simultaneously restrict which Germans could then be allowed to carry out this work, was not paid the attention it would later require. More generally, Anglo-American planning staffs at this time made a number of assumptions which later proved unrealistic. Contrary to their expectations, there was no longer a functioning German administration; the occupation was not brief; and the principle of indirect rule, which had been so successful in the British Empire, was not easily implemented.

One assumption that was particularly detrimental to later public health programmes was the Allies' overestimation of German conditions. Many Anglo-American proposals presented a positive picture of the conditions their officers were going to encounter in Germany. This had important implications. Military government health departments were very small at the outset, since officers were there to supervise the German authorities and control them indirectly, not to carry out the work themselves. The idea that the German standard of living would have to be restricted rather than raised also contained important consequences for public health work. Amid fears that America and Britain were at risk if German industrial strength and military power were not reduced permanently, the German health service was 
identified as one element of the German war machinery. This overestimation also symbolized the extent to which the American and British planners were convinced about the inherent efficiency and functionality of German health and medical organization. Many of the medical officers we have encountered in this chapter believed that the German health administration was so efficient as to need no post-war changes beyond the removal of dangerous Nazi personnel and the annulment of explicitly fascist laws.

Both Soviet and French preparations for the occupation took place not just in the shadow of Anglo-American authorities and priorities, but also in the light of their own security concerns and economic agendas. For both countries, the Second World War began with German invasion, and for both this revived and entrenched much longer-standing anxieties about the German threat. Soviet and French thinking about their occupation of Germany was shaped by the all-important priorities that Germany had to be prevented from conducting another war against them, and that their own economies had to be rebuilt at Germany's expense. To both, German public health only had marginal impact beyond their own security. Competing interests within each country, and, for France, a serious shortage of time, meant that neither occupier arrived in Germany with a clear idea about public health operations beyond the immediate emergency stage, and both drew heavily on SHAEF preparations. Within SHAEF, the framework in which preparations for public health work were made, substantially limited the reach of Allied health work on German soil. Health schemes were designed to accompany and bolster Allied military operations. The extent of destruction and chaos in Germany, the enormous population upheavals, the severe supply shortages, and the absence of any central German organization to be able to take charge - none of this had been foreseen by the Allied health planners. An overestimation of the Germans' standard of living and an underestimation of the Allied public health task in Germany went hand in hand.

\section{Footnotes}

1 Robert Vansittart, The Leopard and the Spots: Selected Extracts from 'Lessons of my Life' (Win the Peace Pamphlet No. 1; London, [1944]), 81.

2 On reservations, see e.g. Alfred Vagts, 'Unconditional Surrender: Vor und nach 1943', Vierteljahreshefte für Zeitgeschichte, 7 (1959), 279-309. Friedrich argued that the call for an unconditional surrender only had propaganda functions, see Carl Joachim Friedrich (ed.), American Experiences in Military Government in World War II (New York, 1948). Also see Ian Kershaw, The End: Hitler's Germany, 1944-1945 (London, 2011).

3 On the EAC, see Boris Meissner, 'Die Vereinbarungen der Europäischen Beratenden Kommission über Deutschland von 1944/45', Aus Politik und Zeitgeschichte, 46 (1970), 3-14. Hans-Günter Kowalski, 'Die European Advisory Commission als Instrument alliierter Deutschlandplanung, 1943-1945', Vierteljahreshefte für Zeitgeschichte, 19 (1971), 261-93. David Reynolds, 'Roosevelt, the British Left and the Appointment of John G. Winant as United States Ambassador to Britain in 1941', International History Review, 4 (1982), 39341310.1080/07075332.1982.9640284 [CrossRef].

4 John Brown Mason, 'Lessons of Wartime Military Government Training', Annals of the American Academy of Political and Social Science, 267 (Jan. 1950), 183-9210.1177/000271625026700120 [CrossRef], at 184.

5 Mason, 'Lessons of Wartime Military Government Training', 185, 189.

6 Balfour, 'Four Power Control in Germany', 92-107.

7 TNA, FO 371/46864, 'The Mentality of the German Officer', Brigadier W. E. van Cutsem (Research Branch, Control Commission for Germany), 15 Jan. 1945.

8 TNA, FO 371/46864, 'The German Character', Brigadier W. E. van Cutsem, 9 Mar. 1945.

9 Some of these are discussed by Ulrich Reusch, Deutsche Berufsbeamten und britische Besatzung: Planung und Politik 1943-1947 (Stuttgart, 1985).

10 IWM Sound Archive, 4483/03, interview with Frances Ludwig Carsten, 2 Oct. 1979. Also see Volker Berghahn, 'Francis L. Carsten, 1911-1998', Geschichte und Gesellschaft, 25 (1999), 504-10.

11 TNA, WO 220/220, 'SHAEF Military Government Handbook for Germany: Prior to Defeat or Surrender'. For a later version, see TNA, FO 371/39166. This handbook has been much discussed in the older historiography on Allied planning, mainly because of its role in the Morgenthau controversy. See e.g. Earl F. Ziemke, The U.S. Army in the Occupation of Germany, 1944-1946 (Washington DC, 1975). F. S. V. Donnison, Civil Affairs and Military Government in North-West Europe 1944-1946 (London, 1961). Harry L. Coles and Albert Weinberg, Civil Affairs: Soldiers Become Governors (Washington, DC, 1964). 
12 See Pogue in Donnison, Civil Affairs, 200.

13 BAK Z45F, 44-45/3/1, 'Manual for Administration and Local Government in Germany', draft prepared by the Branch of the Interior Division, German Country Unit, 19 Aug. 1944.

14 Talcott Parsons, 'The Problem of Controlled Institutional Change', discussed by Uta Gerhard, Talcott Parsons: An Intellectual Biography (Cambridge, 2002), 116-17.

15 Balfour, 'Four Power Control in Germany', 14.

16 Kenneth O. McCreedy, 'Planning the Peace: Operation Eclipse and the Occupation of Germany', Journal of Military History, 65/3 (July 2001), 713-4010.2307/2677532 [CrossRef], at 717.

17 Roosevelt to Stimson, quoted in McCreedy, 'Planning the Peace', 71810.2307/2677532 [CrossRef].

18 Ziemke in McCreedy, 'Planning the Peace', 71810.2307/2677532 [CrossRef].

19 Eva Mayring in Wolfgang Benz (ed.), Deutschland unter alliierter Besatzung, 1945-1949/1955: Ein Handbuch (Berlin, 1999). Also see Adolf Birke et al. (eds.), Akten der britischen Militärregierung in Deutschland, Control Commission for Germany, British Element, Sachinventar (Munich, 1993).

20 Donnison, Civil Affairs, 9.

21 Roosevelt, quoted in Robert Murphy, Diplomat Among Warriors (London, 1964), 281.

22 Winston Churchill, The Second World War, Abridged Edition with an Epilogue on the Years 1945 to 1957 (London, 2002), 879-80.

23 Snell has termed this a 'policy of postponement'. See John L. Snell, Wartime Origins of the East-West Dilemma over Germany (New Orleans, 1959).

24 Herny Morgenthau, Germany Is Our Problem (New York, 1945).

25 See Balfour, 'Four Power Control in Germany', 18.

26 Morgenthau, Germany Is Our Problem, 22.

27 Its effects are overstated in e.g. James Bacque, Other Losses: An Investigation into the Mass Deaths of German Prisoners of War After World War II (1989; London, 1991); James Bacque, Crimes and Mercies: The Fate of German Civilians Under Allied Occupation 1944-1950 (London, 1997); Kurt Keppler, Tod über Deutschland: Der Morgenthau Plan (Tübingen, 1971). It is considered unimportant in e.g. McCreedy, 'Planning the Peace'10.2307/2677532 [CrossRef]; Donnison, Civil Affairs. More balanced assessments are given by John H. Backer, 'From Morgenthau Plan to Marshall Plan', in Robert Wolfe (ed.), Americans as Proconsuls: United States Military Government in Germany and Japan, 1944-1952 (Carbondale, Ill., 1984), 155-65. Bernd Greiner, Die Morgenthau-Legende: Zur Geschichte eines umstrittenen Plans (Hamburg, 1995).

28 McCreedy, 'Planning the Peace', 72010.2307/2677532 [CrossRef].

29 Donnison, Civil Affairs (1961), 201-3.

30 Dagmar Ellerbrock, 'Healing Democracy': Heilende Demokratie (Bonn, 2004), 68 ff.

31 BAK, Z45F, 3/153-3/15, Eisenhower to the Army Groups, subject: 'Policy, Relationship between Allied Occupying Forces and Inhabitants of Germany', 12 Sept. 1944.

32 BAK, Z45F, 44-45/3/1, Chief of Staff (G5, SHAEF) to G5 12th Army Group, G5 6th Army Group, and CO European Civil Affairs Division, subject: 'policy in occupied Germany', 11 Dec. 1944.

33 See n. 32.

34 'Directive of the United States Joint Chiefs of Staff to the Commander-in-Chief of the United States Forces of Occupation regarding the military government of Germany', Apr. 1945, in Beate Ruhm von Oppen, Documents on Germany Under the Occupation, 1945-1954 (London, 1955).

35 'Directive of the United States Joint Chiefs of Staff', Apr. 1945, 15.

36 'Directive of the United States Joint Chiefs of Staff', Apr. 1945, 16.

37 'Directive of the United States Joint Chiefs of Staff', Apr. 1945, 22. 
38 Donnison, Civil Affairs, 28-9. Donnison only talks about civil affairs in general and does not mention health officers or public health work.

39 Donnison, Civil Affairs, 28.

40 Richard Arthur Leiby, Public Health in Occupied Germany, 1945-1949 (PhD, University of Delaware, 1984).

41 BAK, 44-45/11/4, exchange of letters from 13 to 24 Feb. 1945 between Chief Medical Officer (Maj. Gen. A. W. Kenner) and Generals Milburn and Wickersham.

42 BAK, 44-45/11/4, Brigadier General J. E. Lewis to the acting deputy of USGCC, 17 Feb. 1945.

43 TNA, FO 1038/33, Brigadier E. W. Wade, Feb. 1945.

44 e.g. TNA, FO 936/90, W. H. Boucher (Public Health Branch) to J. K. O’Donoghue (Norfolk House), 16 Oct. 1944.

45 BAK, Z45F, 3/169-2/159, Minutes of Meeting convened by Chief, Public Health Branch, G5 Division, SHAEF, 15/16 Jan. 1945. Also Christoph Weisz (ed.), OMGUS-Handbuch: Die amerikanische Militärregierung in Deutschland 1945-1949 (Munich, 1994$), 109$.

BAK, Z45F, 44-45/11/4, Colonel W. L. Wilson (Public Health Branch, G5, SHAEF), 'Concept of Public Health Functions in Germany’, 11 Apr. 1945.

47 Helping the People to Help Themselves (1944), 12.

48 TNA, FO 1050/757, Lt. Gen. B. G. Horrocks (BAOR) to PM Balfour, 12 Sept. 1945.

49 e.g. TNA, FO 936/90, Boucher to Major General S. W. Kirby, 5 Oct. 1944.

50 TNA, FO 936/90, G. Wallace (Establishment Officer, Dept. Health for Scotland, St Andrew's House, Edinburgh) to G. A. Aynsley (Control Commissions, Foreign Office, Norfolk House), 27 Oct. 1944.

51 TNA, MH 76/333, minute by Mr Bliss (Ministry of Health), 6 Jan. 1945.

52 TNA, MH 76/333, C. J. Donelan to Mr Ainsworth, 26 Mar. 1945.

53 TNA, MH 76/333, C. J. Donelan to Mr Ainsworth, 26 Mar. 1945.

54 TNA, MH 76/333, minute by W. W. Andrew, 28 Mar. 1945.

55 TNA, MH 76/333, minute by Whitworth Jones, 28 Mar. 1945.

56 TNA, MH 76/333, minute to Mr Lindsay, 27 Mar. 1945.

57 'From the Archives: The George Medal Winner from Otago Boys', Otago Boys' High School Foundation newsletter, June 2011, http://www.obhsfoundation.co.nz/news_and_events/newsletters/Newsletter-June2011.cfm.

58 TNA, MH 76/333, minute to Mr Lindsay, 27 Mar. 1945.

59 TNA, FO 936/90, W. H. Boucher to Major General S. W. Kirby, 5 Oct. 1944.

60 BAK, Z45F 3/169-2/159, 'Minutes of meeting convened by Chief, Public Health Branch, G5 Division, SHAEF, for Discussion of Military Government Public Health Plans and Operations', 15-16 Jan. 1945, 7.

61 BAK, Z45F 3/169-2/159, 'Minutes of meeting', 15-16 Jan. 1945, 17.

62 BAK, Z45F 3/169-2/159, 'Minutes of meeting', 15-16 Jan. 1945, 25.

63 BAK, Z45F 3/169-2/159, 'Minutes of meeting', 15-16 Jan. 1945, 4.

64 BAK, Z45F 3/169-2/159, 'Minutes of meeting', 15-16 Jan. 1945, 25.

65 TNA, FO 1039/590-592, 21st Army Group, Operation Eclipse, Pamphlet No. 10.

66 TNA, FO 1039/590-592, 21st Army Group, Operation Eclipse, Pamphlet No. 10.

67 Donnison, Civil Affairs, 29.

68 TNA, FO 1038/31, Colonel E. W. Wade (Medical Services Branch) to the Brigadier in charge of Adm. Serv, 10 Nov. 1944.

69 TNA, FD 1/6819, 'Immediate post-war measures of relief and reconstruction in Europe', Sir Frederick Leith-Ross (Royal Institute of International Affairs, Chatham House) to Medical Research Council, 9 Feb. 1942.

70 TNA, FD 1/6819, 'Immediate post-war measures', section A, point 5. 
71 TNA, FD 1/6819, 'Immediate post-war measures', section A, point 7.

72 TNA, FD 1/6819, 'Immediate post-war measures', section D, point 29.

73 TNA, FD 1/6819, 'Immediate post-war measures', section D, point 31(3).

74 TNA, FO 371/31508, J. H. Gorvin (Ministry of Economic Warfare) to Mr T. Zamoyski, (Polish Ministry of Finance), 20 June 1942.

75 TNA, FO 371/31508, Gladwyn Jebb to Mr Makins, Mr Law and Mr Ronald, 4 July 1942.

76 TNA, FO 371/31508, Mr Ronald (Central Department) to Mr Dudley Ward (Ministry of Economic Warfare), 13 July 1942.

77 TNA, FO 371/31508, Gladwyn Jebb, 4 July 1942.

78 'Manifesto', in Emil Ludwig, How to Treat the Germans (London, 1943), 70.

79 TNA, FD 1/6046, 'Germany after the war: a resume with commentary by Lieut. Colonel H. V. Dicks', Feb. $1945,7$.

80 BAK, Z45F 3/169-2/159, Lt. Colonel Cullyford (Chief of the Public Health Branch, G5/Officers Army Group) at the public health meeting of 15-16 Jan. 1945, 25.

81 BAK, Z45F 3/169-2/159, Colonel Stuart Smith (Chief of the SHAEF Supplies Coordinator Section), 10.

82 BAK, Z45F 3/169-2/159, Colonel Scheele (Chief of the SHAEF Preventive Medicine Section), 13.

83 BAK, Z45F 3/169-2/159, Colonel Herrmann (SHAEF Supplies and Economics Branch), 13/14.

84 BAK, Z45F 3/169-2/159, Colonel Wilson, 13.

85 BAK, Z45F 3/169-2/159, Appendix B/3.

86 BAK, Z45F 3/169-2/159, Appendix B/3.

87 BAK, Z45F 3/169-2/159, VI/57-59.

88 BAK, Z45F 3/169-2/159, Appendix B/3.

89 BAK, Z45F 3/169-2/159, 'German War Material required for use in the war against Japan', Annexure III to Appendix F.

90 See TNA, FO 1038/33, correspondence on 'Long Term Medical Policy for Germany'. The terms of reference of this working party were set on 25 Apr. 1945, and the first meeting took place on 1 May 1945, and the second on 1 June 1945. After this, the working party seems to have been disbanded.

91 BAK, Z45F 3/177-1/6, 'Proposed operational plan for public health', HQ, Detachment E1 F3, Regional Command for Bavaria, 12 Apr. 1945.

92 See n. 91.

93 F. S. V. Donnison, Civil Affairs and Military Government: Central Organisation and Planning (London, 1966), 201-3. BAK, Z45F 3/169-2/159, 'SHAEF memorandum on Post Defeat Military Government Planning’, 3 Jan. 1945.

94 BAK, Z45F 44-45/12/5, 'Memorandum on the reorganisation of G5 Division', 24 Mar. 1945.

95 Birke et al. (eds.), Akten der britischen Militärregierung in Deutschland, vol. i, p. xvi.

96 TNA, FO 936/90, ‘New establishment proposal for CCG(BE), Public Health Branch’, 15 Oct. 1945.

97 BAK, Z45F 3/169-2/159, General Draper at the public health meeting of 15-16 Jan. 1945, 15.

98 TNA, FO 936/90, C. H. M. Wilcox (Treasury Chambers) to H. C. Rayner (Enemy Branch), 21 Sept. 1944.

99 TNA, FO 936/90, W. H. Boucher to Mr J. K. Donoghue, 26 Sept. 1944.

100 TNA, FO 936/90, 16 Oct. 1944.

101 TNA, FO 1038/33, War Office to Brigadier Wade, 31 May 1945.

102 BAK, Z45F 3/169-2/159, Colonel Scheele at the public health meeting of 15-16 Jan. 1945, 16.

103 United States Strategic Bombing Survey, Morale Division, Medical Branch Report, The Effect of Bombing on Health and Medical Care in Germany (Washington, 30 Oct. 1945), 1, 5. 
104 BAK, Z45F 3/169-2/159, Colonel Scheele at the public health meeting of 15-16 Jan. 1945, 13.

105 BAK, Z45F 3/169-2/159, Colonel Scheele, 13.

106 BAK, Z45F 3/169-2/159, Colonel Wilson, 9.

107 This was acknowledged by the German Standard of Living Board, set up in summer 1945 to recommend a standard of living for the German peacetime economy. A Sept. 1945 report recognized that it would take at least four years of German recovery to achieve the standard of living of its neighbouring countries. See BAK, Z45F 44-45/6/9, "draft of a preliminary report to the German Standard of Living Board by the working staff of the Board on A Minimum German Standard of Living in Relation to Industrial Disarmament and Reparations', 20 Sept. 1945.

108 BAK, Z45F 3/153-3/15, 'Policy on relations between Allied occupying forces and inhabitants of Germany', 12 Sept. 1944.

109 BAK, Z45F 3/153-3/15, 'Policy on relations between Allied occupying forces and inhabitants of Germany', 12 Sept. 1944.

110 BAK, Z45F 44-45/4/6, 'Policy and instructions on relations with the Germans of Allied Armed Forces and Control Commission Staffs in the initial period of control', 21 Dec. 1944.

111 On Soviet reparation demands, see e.g. Maisky to Molotov, 'Wie hoch sollen die Reparationsforderungen der UdSSR sein?', 15 Dec. 1944, in Jochen Laufer and Georgii Kynin (eds.), Die UdSSR und die deutsche Frage 1941-1948: Dokumente aus dem Archiv für Außenpolitik der Russischen Föderation, i (Berlin, 2004), 502-7.

112 Speech of the Chief Prosecutor of the Soviet Union, Lt. General R. A. Rudenko at the Nuremberg Trials, Feb. 1946, in Vechernyi Leningrad, 12 Feb. 1946, No. 37, 4. Rudenko was appointed as chief prosecutor in Oct. 1945, see Vyvhinskij to Gen. A. A. Sobolev, 6 Oct. 1945, in Laufer and Kynin (eds.), Die UdSSR und die deutsche Frage 1941-1948, 141-2. On the Soviet participation at the Nuremberg Trials, see Francine Hirsch, 'The Soviets at Nuremberg: International Law, Propaganda and the Making of the Postwar Order’, American Historical Review (June 2008), 701-30.

113 On Varga's own writings, see Peter Knirsch, Eugen Varga (Berlin, 1961). Laszlo Tikos, 'E.Vargas Tätigkeit als Wirtschaftsanalytiker und Publizist in der ungarischen Sozialdemokratie, in der Komintern, in der Akademie der Wissenschaften der UdSSR', Arbeitsgemeinschaft für Osteuropaforschung, Forschungsberichte und Untersuchungen zur Zeitgeschichte, 20 (Tübingen, 1965). Gerhard Duda, Jeno Varga und die Geschichte des Instituts für Weltwirtschaft und Weltpolitik in Moskau, 1931-1970 (Berlin, 1994). Eugen Varga: Hervorragender Funktionär der internationalen Arbeiterbewegung und bedeutender marxistisch-leninistischer Wissenschaftler (Leipzig, 1980).

114 e.g. Eugen Varga, 'The Results of Total Mobilisation in Germany' (translation of an article in Pravda for 22 July 1943) (Moscow, 1943) and other articles in Knirsch, Eugen Varga, 88-90. Varga also wrote an article on the historical roots of the peculiarities of German imperialism, published initially in Bolshevik, 11/12 (1943), 39-52; a German translation was published as Die historischen Wurzeln der Besonderheiten des deutschen Imperialismus (Berlin, 1946).

115 e.g. 'Beschluß dess Politbüros des ZK der VKP(b)', 28 Jan. 1942; G. Saksin, 'Vorläufige Materialien zum Bericht des Sekretariats der Kommission über die Tätigkeit der Kommission zur Vorbereitung diplomatischer Materialien für das Jahr 1942', 2 Feb. 1943, both in Laufer and Kynin (eds.), Die UdSSR und die deutsche Frage 1941-1948, 41-2, 89-94, 590.

116 E. Varga to M. Litvinov, 'Sonderbericht: Varianten der Aufgliederung Deutschlands und deren wirtschaftliche und militärische Auswirkungen', 27 Sept. 1943, in Laufer and Kynin (eds.), Die UdSSR und die deutsche Frage 1941-1948, 159-69.

117 See also Gromyko's account of a meeting with Morgenthau, where Morgenthau apparently stated that the United States had no need for German reparations and would not ask for any. Gromyko to Molotov, 13 Nov. 1944, in Laufer and Kynin (eds.), Die UdSSR und die deutsche Frage 1941-1948, 496-501, esp. 500.

118 On Lozovsky and his execution during the 'Night of the Murdered Poets' in Aug. 1952, see e.g. Joshua Rubenstein and Vladimir P. Naumov, Stalin's Secret Pogrom: The Inquisition of the Jewish Anti-Fascist Committee (New Haven, 2001). For a contemporary pen portrait of Palgunov, see Henry C. Cassidy, Moscow Dateline, 1941-1943 (Boston, 1943). Also see Martin Ebon, The Soviet Propaganda Machine (New York, 1987), 172, 179.

119 Jeanette Michelmann, Aktivisten der ersten Stunde: Die Antifa in der sowjetischen Besatzungszone (Cologne, 2002), 57. Michael Iwanowitsch Burzew, Einsichten (Berlin, 1985), 35 ff. Jan Foitzik, Sowjetische Militätadministration in Deutschland (SMAD), 19451949: Struktur und Funktion (Berlin, 1999), 35 ff.

120 Sergeij Semjonow, Von Stalin bis Gorbatschow: Ein halbes Jahrhundert in diplomatischer Mission (Berlin, 1995). Michelmann, 
Aktivisten der ersten Stunde, 57.

121 A. Smirnov to V. G. Dekanozov (Deputy People's Commissar for Foreign Affairs), 31 Dec. 1943, in Laufer and Kynin (eds.), Die UdSSR und die deutsche Frage 1941-1948, 241-4, at 243.

122 A. Smirnov to V. G. Dekanozov, 5 July 1944 and 17 July 1944, both in Laufer and Kynin (eds.), Die UdSSR und die deutsche Frage 1941-1948, 409-15, 417-18. In the latter he included a list of German-speaking Soviet officers who should be appointed to prepare for the occupation.

123 A. Vysinskij to V. M. Molotov, 29 Oct. 1944, and K. Voroshikov to Stalin and Molotov, 29 November 1944, both in Laufer and Kynin (eds.), Die UdSSR und die deutsche Frage 1941-1948, 495, 501.

124 e.g. a pamphlet of the Soviet Party's information bureau from 1 May 1945 pointed out that there was a contradiction between the Americans' tough peace declarations and Eisenhower's plans for the distribution of food supplies in Germany. See Laufer and Kynin (eds.), Die UdSSR und die deutsche Frage 1941-1948, 657. For examples on reviews of the Anglo-American press, see e.g. Litvinov to V. M. Molotov, 'Die Behandlung Deutschlands und anderer Feindstaaten in Europa', 9 Oct. 1943, in Laufer and Kynin (eds.), Die UdSSR und die deutsche Frage 1941-1948, 194-214.

125 A. Smirnov to V. G. Dekanozov, 31 Dec. 1943, in Laufer and Kynin (eds.), Die UdSSR und die deutsche Frage 1941-1948.

126 See e.g. K. V. Novikov to Vyshinskij, 21 Sept. 1944, and Voroshilov to Stalin and Molotov, 22 September 1944, both repr. in Laufer and Kynin (eds.), Die UdSSR und die deutsche Frage 1941-1948 458, 459-60.

127 FRUS, vol. iii. 1945 (1968), 443. Ralf Possekel, 'Sowjetische Speziallager in Deutschland', in Sergei Mironenko et al. (eds.), Sowjetische Speziallager in Deutschland 1945 bis 1950 (Berlin, 1998), ii. 54. Michelmann, Aktivisten der ersten Stunde.

128 Ralf Possekel, 'Sowjetische Speziallager in Deutschland', 54.

129 T. E. Utley, 'French Views', 245.

130 Nehemiah Robinson, 'Problems of European Reconstruction', Quarterly Journal of Economics, 60/1 (Nov. 1945), 15510.2307/1880642 [CrossRef], at 32-3. Robinson later became director of the World Jewish Congress' Institute of Jewish Affairs. On Robinson's work, see Angelika Timm, Jewish Claims against East Germany: Moral Obligations and Pragmatic Policy (Budapest, 1997), 74.

131 French Press and Information Service, Report of 9 Jan. 1945, quoted in Robinson, 'Problems of European Reconstruction', 3.

132 Files of the French Press and Information Service, Session of the French Consultative Assembly on 3 March 1945, quoted in Robinson, 'Problems of European Reconstruction', 3.

133 Report of the Ministry, 1 Aug. 1945, quoted in Robinson, 'Problems of European Reconstruction', 3.

134 'Pour la Victoire', report by P. O. Lapie, 4 Aug. 1945, quoted in Robinson, 'Problems of European Reconstruction', 4.

135 F. Roy Willis, France, Germany and the New Europe, 1945-1963 (Stanford, 1965), 4-5. See also Paul Farmer, Vichy: Political Dilemma (New York, 1955), 111-12.

136 Willis, France, Germany and the New Europe, 4.

137 On this contradiction, see Rainer Hudemann, 'Zentralismus und Dezentralisierung in der französischen Deutschland- und Besatzungspolitik, 1945-1947', in Winfried Becker (ed.), Die Kapitulation von 1945 und der Neubeginn in Deutschland (Cologne and Vienna, 1987), 181-209.

138 Lucius Clay, Decision in Germany (London, 1950), 10.

139 William Strang, Home and Abroad: An Autobiography (London, 1956), 74.

140 Charles de Gaulle, Discours et Messages: Pendant la guerre, juin 1940-janvier 1946 (Paris, 1946), 484.

141 Balfour, 'Four Power Control in Germany', 39.

142 On the effects of the French veto, see e.g. Murphy, Diplomat among Warriors, 371.

143 Michael Mann, Fascists (Cambridge, 2004), 40. Robert Soucy, French Fascism: The Second Wave, 1933-1939 (New Haven, 1995). On the debate about the importance of indigenous French fascism, see also Brian Jenkins (ed.), France in the Era of Fascism: Essays on the French Authoritarian Right (Oxford, 2005). Kevin Passmore, 'The French Third Republic: Stalemate Society or Cradle of Fascism?', French History, 7/4 (1993), 417-49.10.1093/fh/7.4.417 [CrossRef] 
144 In Aug. 1944 the Vichy government established a government in exile, the Commission gouvernementale française pour la défense des intérêts nationaux, based in Sigmaringen (soon to be in the French zone of Germany), headed by Fernand de Brinon. This was dissolved on 22 Apr. 1945; most of its members were eventually sentenced by the new provisional government. Brinon was executed on 15 Apr. 1945. Philippe Pétain (who had not gone on to Sigmaringen) was sentenced to death for treason, but his sentence was commuted to life imprisonment. See e.g. William L. Shirer, The Collapse of the Third Republic: An Inquiry into the Fall of France in 1940 (New York, 1969). Henry Rousso, Pétain et la fin de la collaboration: Sigmaringen 1944-1945 (Brussels, 1999).

145 Reinhard Grohnert, Die Entnazifizierung in Baden 1945-1949: Konzeptionen und Praxis der 'Epuration'am Beispiel eines Landes der französischen Besatzungszone (Stuttgart, 1991), 11-12. Also see Klaus-Dietmar Henke, 'Aspekte französischer Besatzungspolitik in Deutschland nach dem Zweiten Weltkrieg', in Festschrift für Helmut Krausnick zum 75. Geburtstag (Munich, 1980), 169-91, at 178.

146 See Joseph R. Starr, Denazification, Occupation and Control of Germany, March-July 1945 (1950; Salisbury, 1977$), 9$.

147 Grohnert, Die Entnazifizierung in Baden, $11 \mathrm{ff}$.

148 Grohnert, Die Entnazifizierung in Baden, 12-13.

149 Grohnert, Die Entnazifizierung in Baden. See portraits in Claude Albert Moreau and Robert Jouanneau Irriera, Présence Française en Allemagne: Essay de géographie cordiale de la Zone Française d'Occupation (Paris, 1949). On Filippi, see Del Vayo, 'The People's Front', The Nation, 16 Nov. 1946.

150 Starr, Denazification, 9.

151 Christiane Falbisaner-Weeda, 'Mémoires des officiers stagiaires au Centre d'Etudes Germaniques dans l'entre-deux-guerres', Revue d'Allemagne, 34/3 (2002), 327-45.

152 A French translation was completed by Dec. 1944, and published in Mar. 1945 as A.M.F.A. Mémento pour les Officiers de Détachements de Gouverment Militaire. Jérôme Vaillant, 'Bedeutung und Ausmaß des französischen Einflusses auf die kulturelle Entwicklung im Nachkriegsdeutschland', in Vaillant (ed.), Französische Kulturpolitik in Deutschland, 1945-1949: Berichte und Dokumente (Konstanz, 1984), 11. Grohnert, Die Entnazifizierung in Baden, 13. Also see COL, AC 836, Enemy Branch, Foreign Office and Ministry of Warfare, London, 'Germany Basic Handbook', Aug. 1944. 


\section{Figures}

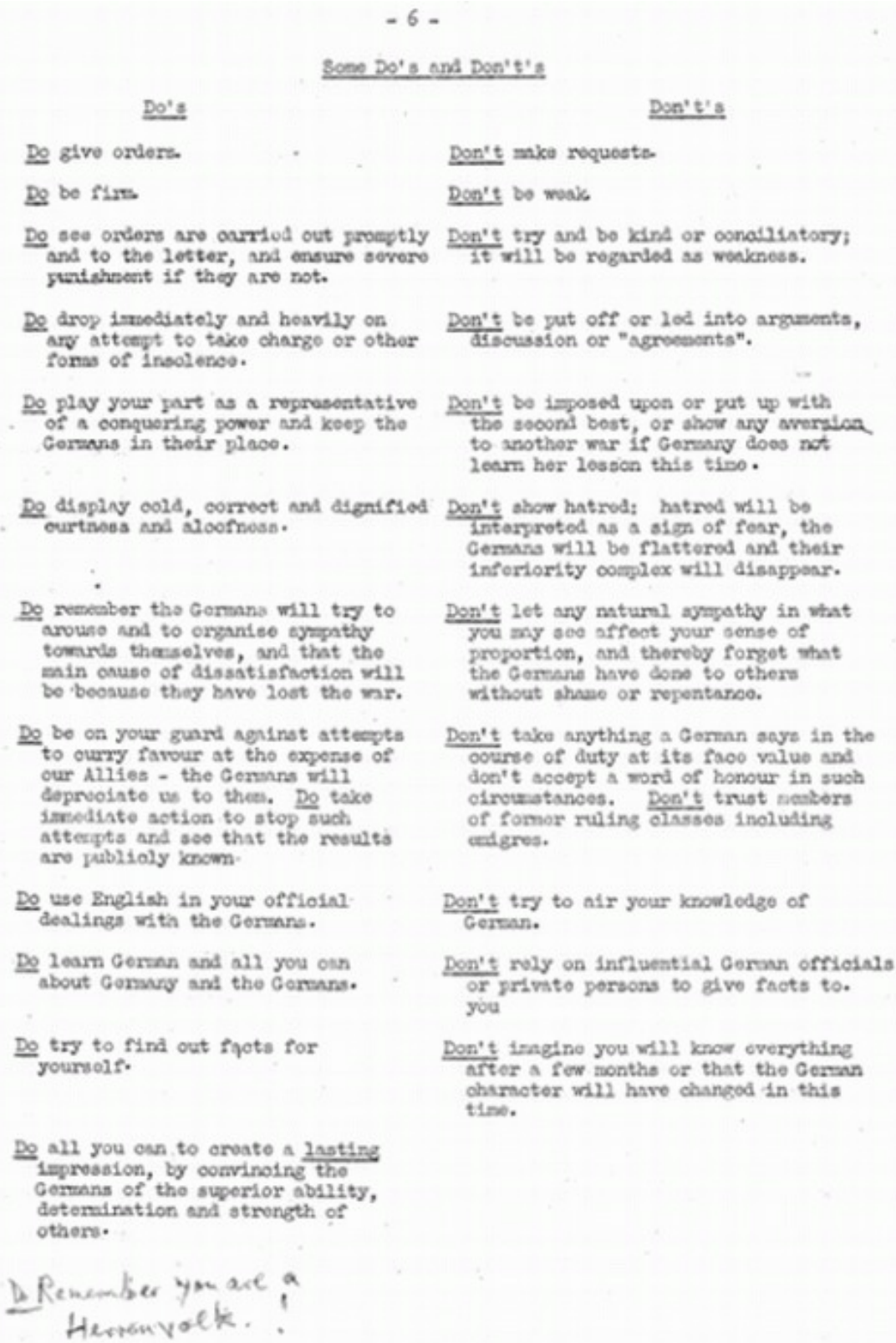

\section{Figure 2.1.}

'Some Do's and Don'ts', British Control Commission paper 'The German Character', 9 March 1945

This material is not covered by the Creative Commons licence terms that govern the reuse of this publication. For permission to reuse please contact the rights holder directly.

\section{(C) Jessica Reinisch 2013.}

This is an open access publication. Except where otherwise noted, this work is distributed under the terms of a Creative Commons AttributionNonCommercial- NoDerivatives 4.0 International licence (CC BY-NC-ND), a copy of which is available at http://creativecommons.org/licenses/by-ncnd/4.0/ Enquiries concerning use outside the scope of the licence terms should be sent to the Rights Department, Oxford University Press, at the above address.

Monographs, or book chapters, which are outputs of Wellcome Trust funding have been made freely available as part of the Wellcome Trust's open access policy

Bookshelf ID: NBK293860 